Article

\title{
Evaluating the Impacts of Ground and Atmospheric Conditions on the Efficiency of Solar Energy System and Its Economic Analysis
}

\author{
Ali Saleh Aziz ${ }^{1}$, Mohammad Faridun Naim Tajuddin ${ }^{1}$, Sanjeevikumar Padmabaran 2,*, Lucian \\ Mihet-Popa 3, Mohd Rafi Adzman 1, Makbul A. M. Ramli ${ }^{4}$ \\ 1 School of Electrical Systems Engineering, Universiti Malaysia Perlis, 02600 Arau, Malaysia; \\ iraq_1991@yahoo.com (A. S. Aziz), faridun@unimap.edu.my (M.F.N Tajuddin), mohdrafi@unimap.edu.my \\ 2 Department of Energy Technology, Aalborg University, 6700 Esbjerg, Denmark; san@et.aau.dk \\ 3 Faculty of Engineering, Østfold University College, Kobberslagerstredet 5, 1671 Kråkeroy, Norway; \\ lucian.mihet@hiof.no \\ 4 Department of Electrical and Computer Engineering, King Abdulaziz University, Jeddah 21589, Saudi \\ Arabia ; mramli@kau.edu.sa \\ * Correspondence: email: lucian.mihet@hiof.no (L.M.-P.); Tel.: +47-922-713-53
}

\begin{abstract}
The There are many factors influencing the performance of photovoltaic (PV) systems. Among these factors, temperature and solar radiation are two major parameters that have a large effect on the efficiency of PV systems. The cell temperature of PV panels is related to the ambient temperature while the solar radiation incident on the surface of the PV modules depends on the slope and azimuth of these modules. Furthermore, ground reflectance (albedo) affects the irradiance incident on the PV panel surface, which in turn affects the output of a PV system. Nevertheless, the effects of these factors on the economic performance of the solar PV systems are scarcely reported. This paper presents a complete design of a stand-alone PV/battery system to supply electric power for a mobile base station in Choman, Erbil, Iraq. The effects of different factors on the total electricity produced by PV arrays and its economic performance are simultaneously investigated. HOMER software has been used as a tool for the techno-economic and environmental analysis. As indicated from the simulation results, the PV array capacity and its economic performance are highly affected by the variation of the slope and azimuth. With a base case (albedo of $20 \%$ and average annual ambient temperature of $11^{\circ} \mathrm{C}$ ), the best feasible system which is achieved by facing PV due to south with a tilt angle of $40^{\circ}$ or $45^{\circ}$, is found to have net present cost (NPC) of $70595 \$$ and cost of energy (COE) of $0.54 \$ / \mathrm{kWh}$. Moreover, the results indicate that increasing the ground reflectance from $10 \%$ to $90 \%$ results in a $7.2 \%$ decrease in the PV array capacity and about 3\% decrease in the NPC and COE. On the other hand, increasing the ambient temperature from $0^{\circ} \mathrm{C}$ to $40^{\circ} \mathrm{C}$ results in a $19.7 \%$ increase in the PV array capacity and an $8.2 \%$ increase in the NPC and COE. Furthermore, according to the ambient temperature of Choman, using PV modules with high sensitivity to temperature is found to be an attractive option. Provided simulation performance analysis proves that the studied parameters must be treated well to establish an enabling environment for solar energy development in Iraq.
\end{abstract}

Keywords: Renewable Energy; solar energy; PV panels slope; azimuth; temperature; albedo

\section{Introduction}

The rapid growth of the global population and industrial sector has resulted in a significant increase in electricity demand. Non-renewable energy resources such as oil, coal, and gas are usually used in the conventional electricity generation systems. However, utilization of these resources causes carbon dioxide $\left(\mathrm{CO}_{2}\right)$ and other harmful pollutants to be emitted into the atmosphere which are hazardous to our environment [1-2]. Meanwhile, the ever increasing and continuously unpredictable fluctuating fossil fuels encourages nations to search for new energy sources [3-4]. 
Consequently, researchers, environmentalist, and policy makers, around the world are currently looking for vast potential sources of renewable energy to minimize the use of the conventional fossil fuel and hence progressive reduction of emissions [5]. Studies indicate that, in order to minimize the impact of pollution in our environment, the share of electricity generated from renewable sources must be increased up to $37 \%$ by 2040 as compared to current scenario of $23 \%$ [6]. However, in 2016, more than 170 countries adopted at least one type of renewable energy source (RES) target, an upward trend from only 43 countries in 2005. Figure 1 shows the historical trends and future projections for the world's energy use and carbon emissions [7]. The chart presents that $\mathrm{CO}_{2}$ emissions level after 2014 is approximately constant in spite of the sharp increase in energy demand in the future which indicates the increase of renewable energy sources rate.

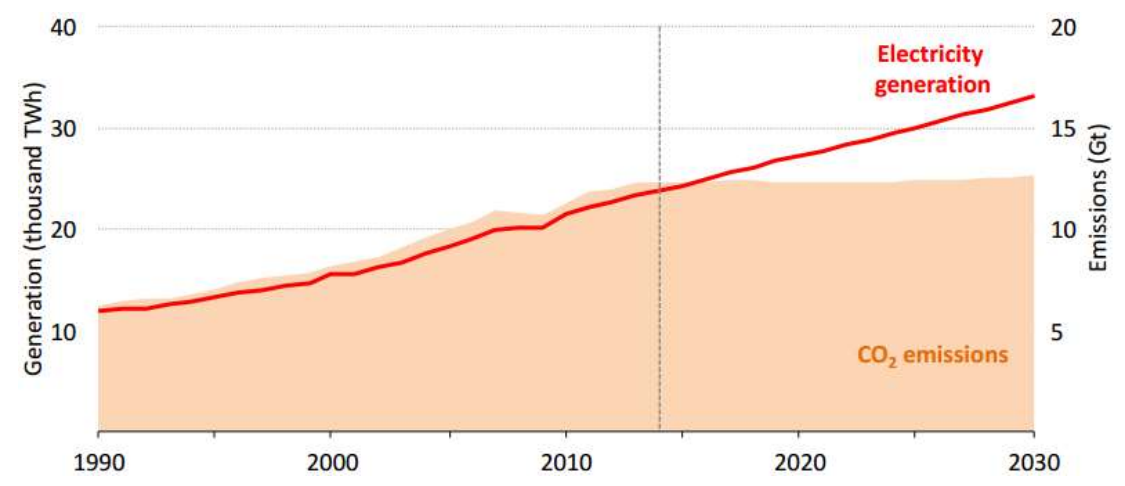

Figure 1. Historical trends and future projections for the world's energy use and carbon emissions

Solar energy is the most plentiful source of energy on the earth. Therefore, solar photovoltaic (PV) energy conversion is potentially the largest and most widely used system as compared to other renewable energy technologies. It significantly reduces the negative environmental, economic, and health aspects of anthropogenic climate change through reductions of greenhouse gas emissions. Although PV energy technology is becoming much more economically competitive with electricity from conventional sources in many countries, economic aspect is still the main barrier to exploitation of this source of energy while remaining within the necessary physical limits of life cycle carbon emissions. In order to minimize the atmosphere's $\mathrm{CO}_{2}$ level, this would require a significant increase in the PV capacity from gigawatt to tera-watt level. In this context, optimization of the electrical output on a per cost basis is important to speed up the diffusion of solar PV technologies [8].

The performance of PV module in outdoor conditions depends on many factors such as types of PV technologies and the environmental conditions of the place where the modules are installed. To design a solar system for a selected region, these factors must be taken into consideration [9-10]. The temperature is one of the most remarkable environmental factors affecting the efficiency of PV. The ambient air temperature and the cell temperature of a PV are not equal since PV arrays are dark in color and therefore tend to absorb a larger amount of the sun's energy. During the sunlight hours, a solar cell temperature becomes higher than the ambient temperature by a factor that depends on insulation. The short circuit current increases while the maximum power, efficiency, fill factor, and open circuit voltage decrease when the cell temperature increases [11]. Ike [12] tested the impacts of temperature on the output of a PV system in eastern Nigeria. He concluded that the utilization of PV system for electricity generation is not preferable in places with very high ambient temperature. Therefore, installing PV panels in areas that enjoy higher air current is favorable since the temperature tends to be low which leads to increase the efficiency of the panels. In [13], the authors discussed the impact of the temperature and light intensity on the output performance of the crystalline solar panels. They found that PV cell temperature has a large influence on the performance of the solar system. They concluded that the maximum power and efficiency decreases significantly with increasing the cell temperature. The feasibility study of grid connected PV system to provide electricity for Algerian rural areas by considering the effect of the ambient temperature on the 
performance of the system was investigated in [14]. Their results indicated that the optimal system increases by $480 \mathrm{Wp}$ when the average annual ambient temperature increases from 18 to $40{ }^{\circ} \mathrm{C}$.

The total solar radiation consists of a direct/beam, diffuse, and reflected radiation. Direct radiation is coming directly from the sun down to the surface of the Earth in which no clouds blocked the sun. Diffuse radiation is the radiation found in cloudy day that reaching the Earth's surface after having been scattered by molecules and particles in the atmosphere. There is also a small amount of radiation reflected from the clouds and Earth's surface, which is usually called reflected radiation. The components of global solar radiation are shown in figure 2 [15]. Ground reflectance (also called albedo) can be defined as the ratio of the amount of reflected radiation to the total amount incident on the ground. Among various surface types on the earth, ice and snow have the high ground reflectance. In the Arctic region, the surface albedo variations have large effects on the irradiative budget of the earth atmosphere system and hence on the global climate [16-18].

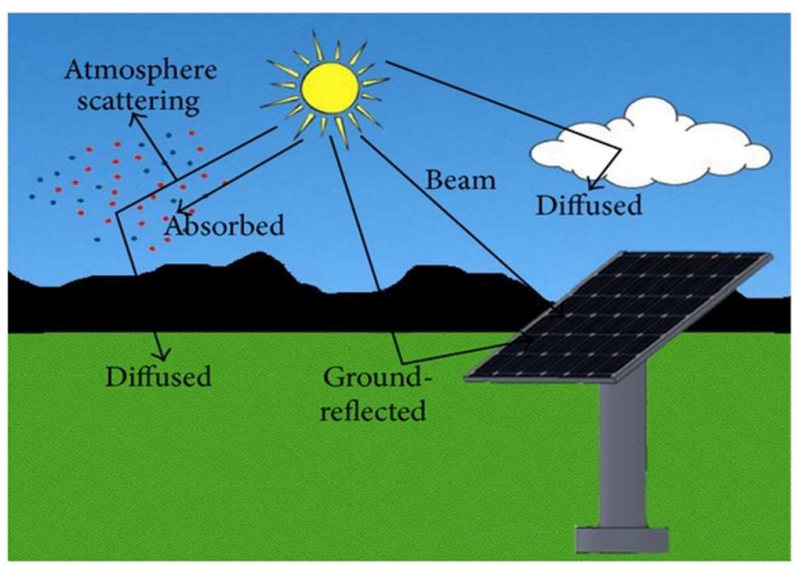

Figure 2. Components of global solar radiation

The ground albedo varies from place to place as well as from time to time in the same location as a result of the variations in the properties of ground surface material, solar position, cloud cover, snow cover and ground vegetation. In the case of the ideal black bodies, the albedo is $0 \%$, while it is $100 \%$ for the ideal white bodies. Generally, it is possible to estimate the ground albedo of any surface from its color. Albedo radiation affects the spectral distribution of the incident radiation on the PV arrays, and hence affects the performance of the PV system [6]. Guechi and Chegaar [19] evaluated the impact of varying the ground reflectance on the conversion efficiency of amorphous (a-Si: $\mathrm{H}$ ) and indium gallium phosphide (InGaP) solar cells for two different sites in Algeria. They found that the output of PV increases with increasing the ground reflectivity. Moreover, the effect of albedo is greater for InGaP than a-Si: H. In [20], the authors presented a numerical approach to estimate the ground-reflected radiation for any viewing surface and the effect of this reflectivity on the Performance of PV Systems. They reported that utilization of a high-reflectance material for foreground leads to increase the output of PV by a third.

PV must be designed and installed in such a way to produce the maximum amount of energy, this helps to reduce the required capacity of PV and the cost of equipment. This can be achieved by mounting the generic solar collectors at right angles to the sun's rays [21]. PV tilt and azimuth angles have a large effect on the performance of a solar collector. This is according to the fact, optimum PV orientation and inclination depends on the latitude, temporal profile, local climate and load consumption [22]. It is generally known that the default value of tilt angle that is equal to the area's latitude minus 15 degrees in summer and plus 15 degrees in winter to an azimuth angle that is parallel to the equator should maximize the output of the solar panels [23]. There are many research papers regarding the optimum tilt angle which presents different recommendations. Benghanem [24] carried out an analysis of different tilt angles of the solar panel in order to maximize the solar irradiation for Madinah, Saudi Arabia. He suggested that the tilt angle for should be $12^{\circ}$ more than the latitude 
during winter and $13^{\circ}$ less than the latitude during summer. The optimum annual tilt angle for the location was found to be close to the latitude angle. The optimum tilt angle for fixed-array solar panels at constant latitude of $29^{\circ}$ was discussed in [25]. The authors concluded that the tilt angle for Shiraz, Iran is equal to the latitude minus 24 in summer and plus 14 in winter. In [26], the effects of array inclination and orientation on solar panel output in Northern Ireland (latitude: $15^{\circ}$ ) was analyzed. The optimum PV output was found to be for a south facing surface with a tilt angle varies from $20^{\circ}$ in summer to $60^{\circ}$ in winter.

However, although the influence of ambient temperature on the efficiency of the solar panels is well known, selecting of suitable PV modules based on its sensitivity to temperature is rarely discussed. Moreover, the effect of ground reflectance (albedo) on PV performance is scarcely reported. Furthermore, the output of PV arrays under various ambient temperatures, tilt angles, orientations and albedo is seldom correlated with the economic analysis of the PV systems. In this research, a techno-economic feasibility study has been performed to investigate the optimum configuration of a standalone PV/battery power system for a mobile tower site in a remote village in Erbil, Iraq, using HOMER simulation software. In order to accurately investigate the effect of slope angle, azimuth angle, temperature, and ground reflectance variations on the performance of photovoltaic cells and the total cost of the system, a sensitivity analysis has been done. The rest of this paper is structured as follows: Section 2 presents the methodology of the research which includes a description of the used software, selected sites, data for load and resource assessment, mathematical representations, configuration of the system, and economic parameter. The results and discussions about each parameter are presented in section 3. Finally, the conclusion of this work is illustrated in section 3 .

\section{Methodology}

\subsection{HOMER Software}

HOMER, which is developed by the National Renewable Energy Laboratory (NREL), is computer software that significantly simplifies the design process for identifying least-cost feasible system of varied off/on grid systems. Simulation, optimization, and sensitivity analysis are the main three tasks performed in HOMER. It helps the modeler to compare various renewable energy systems over a wide range of applications considering the techno-economic features of system components $[26,27,28]$.

\subsection{Description of the Selected Site}

The selected area is part of the Qandil Range (a part of the Zagros Range) and is located in Choman District, Erbil, Iraq. The height of Haji Ibrahim, reaches $3587 \mathrm{~m}$ which is the highest peak in the area. It is enclosed by many other mountains, including Mt. Gardamn to the north, Mt. Sakran to the south, and Mt. Halgurd to the west. The snow covers the peak of mountains throughout the year. The area has many small rivers and streams. Moreover, these mountains contain thorn-cushion vegetation habitats, mountain riverine forest and oak woodlands. Figure 3 shows a picture for the selected site [29].

Despite the availability of the conventional energy resources, a huge electricity shortage started in 1991 because of the disruption caused by the war [30]. The electricity in Choman is available for a few hours per day. Most people depend on their own generators during the shortage of electricity. 


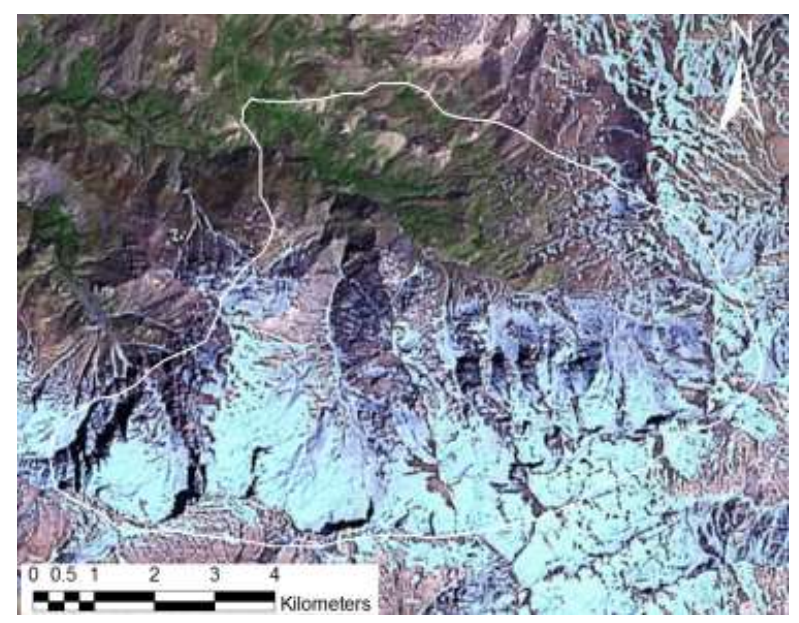

Figure 3. Picture for the selected site

\subsection{Data for Load and Resource Assessment}

\subsubsection{User Load}

The Load estimation is calculated based on consumption of electrical appliances used in the mobile network site. The load demand of a BTS depends on the number of parameters such as the area to be covered, the topography of this area, and the utilized technologies. The daily load demand of the site for a typical day is presented in Figure 4. Hour-by-hour electrical load of the village is artificially generated by HOMER software. In order to account for the variation in daily load power consumption, random variable from hour to hour and from day to day has been proposed, with each approximated to be around 10\%. Figure 5 shows the monthly load profile of the site.

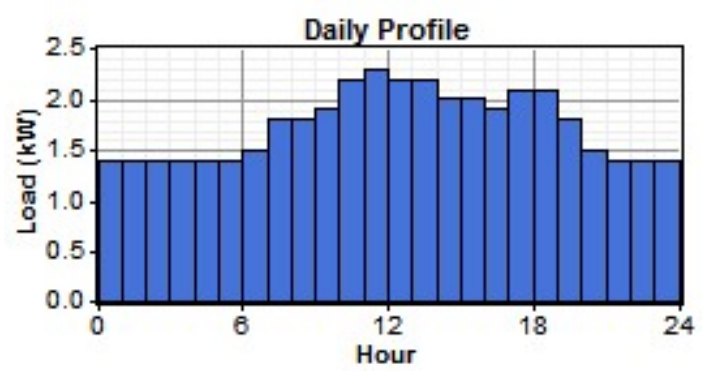

Figure 4. Daily load demand of the selected mobile base station

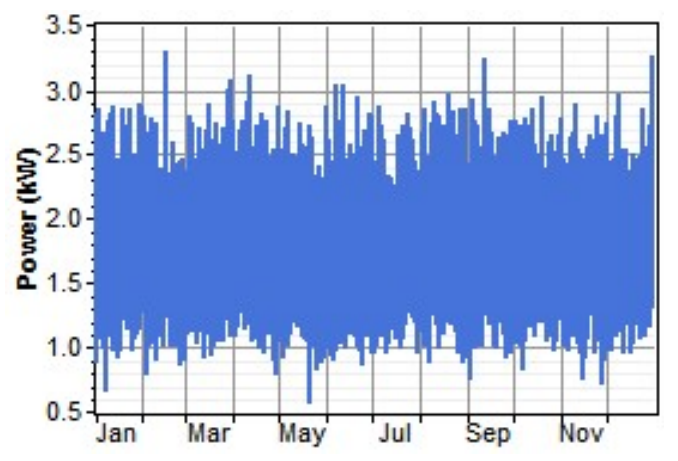

Figure 5. Monthly load demand of the selected mobile base station 
Figure 6 presents the monthly average clearness index and solar radiation in Choman. The latitude and longitude of latitude $36^{\circ}$ north and $44^{\circ}$ east respectively, are considered in this study. The solar radiation varies between $2.180 \mathrm{kWh} / \mathrm{m}^{2} /$ day in December and $7.670 \mathrm{kWh} / \mathrm{m}^{2} /$ day with an annual average value of $4.8663 \mathrm{kWh} / \mathrm{m}^{2} /$ day. It can be noted that that the radiation is low in winter and high in summer.

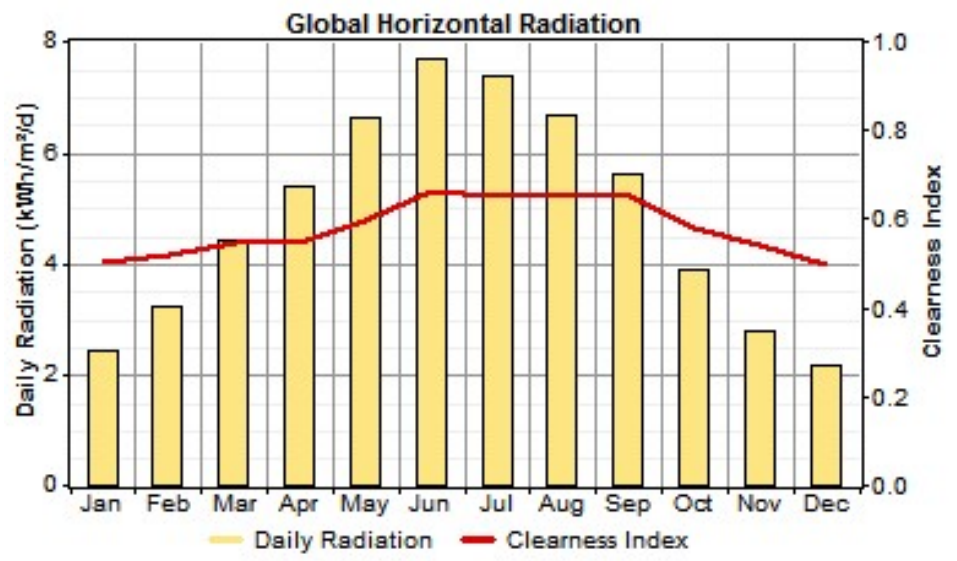

Figure 6. Monthly averaged solar radiation and clearness index in Choman District

\subsubsection{Ambient Temperature}

In order to accurately calculate the output power of PV, the effect of ambient temperature on the performance of PV is taken into account. Figure 7 presents the average monthly air temperature of Choman [31]. It is clear that the highest and lowest average temperatures are obtained to be around 23.8 and $-0.4{ }^{\circ} \mathrm{C}$ in July and January respectively. The annual average ambient temperature is found to be $11^{\circ} \mathrm{C}$.

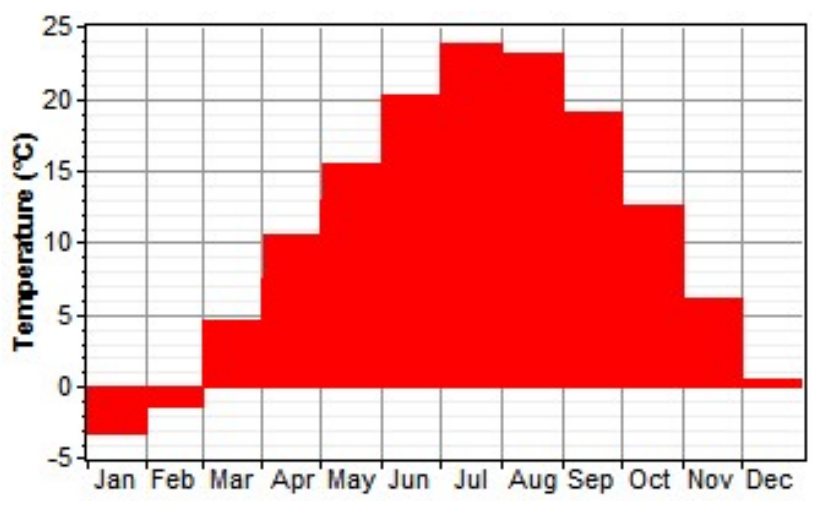

Figure 7. Monthly averaged ambient temperature in Choman District

\subsection{Mathematical Representations}

\subsubsection{Calculation the Global Radiation Incident on the Solar Panels}

In this study, the orientation of the PV array is described using two factors, a tilt angle and an azimuth. The angle between the horizontal and the surface of the PV-array is called a tilt angle. A zero tilt angle represents a horizontal orientation, while a ninety degree refers to a vertical orientation. The azimuth is the direction that the surface faces. In HOMER software, azimuth of 0, -90, 90, 180 degrees corresponds to south, east, west, and north respectively. Figure 8 shows the orientation of the PV-array panel [32]. The value of azimuth angle is presented in Table 1 [33]. 


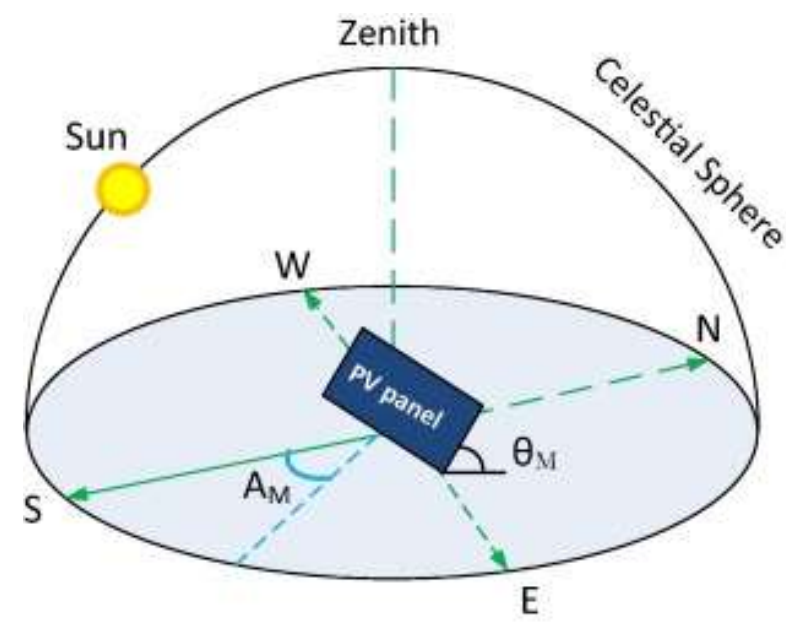

Figure 8. PV tilt $\left(\theta_{M}\right)$ and azimuth (Ам) angles

Table 1. The value of azimuth angle

\begin{tabular}{cl}
\hline Heading & Azimuth angle $\left(^{\circ}\right)$ \\
\hline South & 0 or 360 \\
South-West & 45 \\
West & 90 \\
North-West & 135 \\
North & 180 \\
North-East & 225 or -135 \\
$\quad$ East & 270 or -90 \\
South-East & 315 or -45 \\
\hline
\end{tabular}

The time of day, time of year, and latitude is other parameters related to the geometry of the situation. The solar declination is highly affected by the time of year, which is the latitude at which the sun is directly overhead at solar noon. In HOMER, Solar declination is calculated using the following expression $[2,33,34]$ :

$$
\delta=23.45^{\circ} \sin \left(360^{\circ} \frac{284+n}{365}\right)
$$

where $n$ is a the day of the year (from 1 to 365).

The sun is influenced by the time of the day. This can be represented by an hour angle, which is negative in the morning, zero at solar noon, and positive in the afternoon. The hour angle is estimated using the following equation [34, 35]:

$$
\omega=\left(t_{s}-12 h r\right) \cdot 15^{\circ} / h r
$$

where $t_{s}$ represents the solar sunset time [hr]

The value of $t_{s}$ at the solar noon is $12 \mathrm{hr} ., 90$ minutes later, it becomes $13.5 \mathrm{hr}$. This can be explained by the fact that for each hour, the sun moves through an arc about 15 degrees. 
One of the assumptions in HOMER is that all time-dependent data, like electrical load and solar irradiation are specified in civil time, which is also known as a local standard time. The civil time can be calculated using the following equation $[34,35]$ :

$$
t_{s}=t_{c}+\frac{\lambda}{15^{o} / h r}-Z_{C}+E
$$

where $t_{c}$ is the civil time in hours accounted to the center middle of the time step [hr], $\lambda$ represents the longitude $\left[{ }^{\circ}\right], Z_{c}$ is the time zone to east of Greenwich mean time [hr], $E$ is the time equation [hr].

Both the earth's orbit eccentricity and the slope of the earth's rotational axis related to the ecliptic plane are taken into consideration in the equation of time which is determined as follows [34, 35]:

$$
E=3.82(0.000075+0.001868 \cos B-0.032077 \sin B-0.014615 \cos 2 B
$$$$
-0.04089 \sin 2 B)
$$

where $B$ is given by $[28,29]$ :

$$
B=360^{\circ} \frac{n-1}{365}
$$

It is possible to estimate the angle of incidence for a surface with any orientation using the following expression [33, 34]:

$$
\begin{gathered}
\cos \theta=\sin \delta \sin \phi \cos \beta-\sin \delta \cos \phi \sin \beta \cos \gamma+\cos \delta \cos \phi \sin \beta \cos \omega \\
\cos \delta \sin \phi \sin \beta \cos \gamma \cos \omega+\cos \delta \sin \beta \sin \gamma \sin \omega
\end{gathered}
$$

where $\theta$ refers to the incidence angle, $\varnothing$ represents the hour angle, $\beta$ is the surface tilt angle, $\gamma$ is the surface azimuth angle, $\delta$ is the latitude, and $\omega$ is the solar declination.

The distance between the subsolar point and the latitude is called the zenith angle. It is equal to $0^{\circ}$ when the sun lies directly overhead and increases until reaching $90^{\circ}$ at the horizon. The zenith angle is calculated by setting the surface tilt angle $(\beta)$ equal to zero, which yields [33, 34]:

$$
\cos \theta_{z}=\cos \phi \cos \delta \phi \cos \omega+\sin \phi \sin \delta
$$

Where $\theta z$ refers to the zenith angle $\left[{ }^{\circ}\right]$

To calculate the amount of solar radiation at the top of the earth's atmosphere, striking a surface normal (perpendicular) to the sun's rays which is known as the extra-terrestrial normal radiation, HOMER uses the following equation $[2,34,29]$ : 


$$
G_{o n}=G_{s c}\left(1+0.033 \cos \frac{360 n}{365}\right)
$$

where $G_{o n}$ represents the extra-terrestrial normal solar irradiance $\left[\mathrm{kW} / \mathrm{m}^{2}\right]$ and $G_{s c}$ is the solar constant $\left[1.367 \mathrm{~kW} / \mathrm{m}^{2}\right]$

The following expression is used to calculate the extra-terrestrial horizontal radiation [34, 36]:

$$
G_{o}=G_{o n} \cos \theta_{z}
$$

where $G_{o}$ refers to the extra-terrestrial horizontal solar irradiance $\left[\mathrm{kW} / \mathrm{m}^{2}\right]$

To obtain the average extra-terrestrial horizontal solar irradiance over the time step, equation (8) needs to be integrated over one-time step as follows [33, 35]:

$$
\bar{G}_{o}=\frac{12}{\pi} G_{o n}\left[\cos \phi \cos \delta\left(\sin \omega_{2}-\sin \omega_{1}\right)+\frac{\pi\left(\omega_{2}-\omega_{1}\right)}{180^{\circ}} \sin \phi \sin \delta\right]
$$

Where $\bar{G}_{o}$ represents average extra-terrestrial horizontal solar irradiance over the time step $\left[\mathrm{kW} / \mathrm{m}^{2}\right], \omega_{1}$ represents the solar time angle at the start of the period $\left[^{\circ}\right]$, and $\omega_{2}$ refers to the solar time angle at the end of the period $\left[^{\circ}\right]$.

The clearness index is the ratio of the total horizontal irradiance to the extra-terrestrial horizontal solar irradiance. It can be defined using the following equation [34, 36]:

$$
K_{t}=\frac{\bar{G}}{G_{o}}
$$

where $K_{t}$ represents the clearness index and $\bar{G}$ refers to the average global horizontal irradiation on the surface of the earth over the time step $\left[\mathrm{kW} / \mathrm{m}^{2}\right]$ which is the summation of beam (direct) and diffuse radiation as expressed by the following equation [33, 35]:

$$
\bar{G}=\bar{G}_{b}+\bar{G}_{d}
$$

Where $\bar{G} b$ represents the direct radiation $\left[\mathrm{kW} / \mathrm{m}^{2}\right], \bar{G}_{o}$ refers to the diffuse radiation $\left[\mathrm{kW} / \mathrm{m}^{2}\right]$.

The total horizontal irradiance is resolved into its direct and diffuse components in to obtain the solar irradiance falling on the surface of PV panels. The diffuse solar fraction as a function of the clearness index is given in the following expression [34,37]:

$$
\frac{\bar{G}_{d}}{\bar{G}}=\left\{\begin{array}{c}
1-0.09 * K_{T} \text { for } K_{T} \leq 0.22 \\
0.9511-0.1604 K_{T}+4.388 K_{T}^{2}-16638 K_{T}^{3}+12336 K_{T}^{4} \text { for } 0.22 \leq K_{T} \leq 0.80 \\
0.165 \text { for } K_{T}>0.80
\end{array}\right.
$$


The average total horizontal irradiance is used to obtain the clearness index for each time step and the diffuse radiation. Then, the diffuse radiation is subtracted from the global horizontal radiation to calculate the direct radiation.

The ratio between the direct irradiance on an inclined surface to direct radiation on the horizontal surface is called the conversion factor for direct radiation $\left(\mathrm{R}_{\mathrm{b}}\right)$, It can be calculated as follows [34, 37]:

$$
R_{b}=\frac{\cos \theta}{\cos \theta_{z}}
$$

The anisotropy index $(A i)$ is a measure of transparency of the atmosphere for direct radiation. It can also be used for the estimation of the amount of circum solar diffuse radiation, and defined as $[34,37]$ :

$$
A_{i}=\frac{\bar{G}_{b}}{G_{o}}
$$

Another parameter needs to define is the one used for consideration of the fact that diffuse irradiance coming from the rest of the sky is less than of that comes from the horizon. This parameter is relative to the cloudiness and can be determined using the following expression [34, 37]:

$$
f=\sqrt{\frac{\bar{G}_{b}}{\bar{G}}}
$$

where $f$ refers to the horizon brightening factor

The total radiation incident on the solar panels can be expressed by using the Hay-DaviesKlucher- Riendl (HDKR) model as follows [34, 37]:

$$
\bar{G}_{T}=\left(\bar{G}_{b}+\bar{G}_{d} A_{i}\right) R_{b}+\bar{G}_{d}\left(1-A_{i}\right)\left(\frac{1+\cos \beta}{2}\right)\left[1+f \sin ^{3}\left(\frac{\beta}{2}\right)\right]+\bar{G} \rho_{g}\left(\frac{1-\cos \beta}{2}\right)
$$

where $\rho_{g}$ represents the ground reflectance [\%].

The ground reflectance of various surfaces is presented in table 2 [38]. According to the weather conditions of Choman, the ground cover tends to be grass in summer and snow in winter. Also, sometimes, both are available in the same area and same time. Therefore, in this study, different value of ground reflectance is considered to investigate the impact of this variation on PV efficiency and cost.

Table 2. Reflectivity values of various surfaces

\begin{tabular}{cc}
\hline Type of Ground Cover & Albedo \\
\hline Forest (Coniferous) & $0.15-0.20$ \\
Forest (Delicious) & $0.15-0.20$ \\
Soil (Light \& dry) & $0.05-0.4$
\end{tabular}




$\begin{array}{cc}\text { Soil (Dark \&wet) } & 0.05-0.4 \\ \text { Tundra } & 0.18-0.25 \\ \text { Agricultural crops } & 0.18-0.25 \\ \text { Grass (Long to short) } & 0.16-0.26 \\ \text { Snow (old to fresh) } & 0.40-0.95\end{array}$

\subsubsection{Calculates the Temperature of the Solar Panels}

The PV cell temperature $T_{c}$ is the temperature of the solar panel surface. By night, the PV cell temperature and ambient temperature are equal, but during the sunlight hours, the cell temperature exceeds the ambient temperature with $30^{\circ} \mathrm{C}$ or up. The following expression is used to obtain the PV cell temperature [39]:

$$
T_{c}=T_{a}+G_{T}\left(\frac{T_{c, N O C T}-T_{a, N O C T}}{G_{T, N O C T}}\right)\left(1-\frac{\eta_{c}}{\tau \alpha}\right)
$$

where $T_{a}$ represents the ambient air temperature $\left[{ }^{\circ} \mathrm{C}\right], T_{c, N O C T}$ refers to the nominal operating cell temperature $\left[{ }^{\circ} \mathrm{C}\right], T_{a, N O C T}$ represents the ambient temperature at NOCT $\left(20^{\circ} \mathrm{C}\right), G_{T, N O C T}$ is the solar radiation at NOCT $\left(0.8 \mathrm{Kw} / \mathrm{m}^{2}\right), \eta_{c}$ is the efficiency of the solar array $(\%), \tau$ refers to the solar transmittance of enclosure cover over the solar array [\%] and $\alpha$ represents the solar absorptance of the solar array [\%].

If the maximum power point tracker (MPPT) is used with solar system, PV works at the maximum power point which maximizes its efficiency. PV cell temperature with MPPT can be determined using [39]:

$$
T_{c}=T_{a}+T_{c, N O C T}-T_{a, N O C T}\left(\frac{G_{T}}{G_{T, N O C T}}\right)\left(1-\frac{\eta_{m p}}{\tau \alpha}\right)
$$

where $\eta_{m p}$ refers to the PV array efficiency at MPPT which is defined using the following expression [37]:

$$
\eta_{m p}=\eta_{m p, S T C}\left[1+\alpha_{p}\left(T_{c}-T_{c, S T C}\right)\right]
$$

where $\eta_{m p, S T C}$ represents the solar array efficiency at its MPPT under STC [\%], $\alpha_{p}$ represents the temperature coefficient of power $\left[\% /{ }^{\circ} \mathrm{C}\right], T_{c, S T C}$ refers to the cell temperature under STC.

The temperature coefficient of power is used to explain how the cell temperature can affect the output power of the PV. Solar panels have negative temperature coefficients of power which indicates that when the PV cell temperature increases, the output of the PV system decreases. The value of the nominal operating cell temperature (NOCT) and temperature coefficient of power and depend on PV module type. Silicon is the main material utilized for the production of solar cells. Mono-crystalline, polycrystalline and thin film or amorphous are the major types of solar panels that are commercially available in the market. Mono-crystalline solar cells form of a homogeneous silicon crystal. Polycrystalline solar cells are composed of a number of smaller crystals. While, thin film solar cells are formed by embedding few layers of silicon on other material surfaces, such as a glass [40]. Table 3 shows characteristic values of PV module under standard technologies [37].

Table 3. The characteristic values of PV module under standard technologies

\begin{tabular}{cccc}
\hline PV Module Type & $\begin{array}{c}\text { Average Value } \\
\text { of } \boldsymbol{\eta}_{m p, S T C}\end{array}$ & $\begin{array}{c}\text { NOCT } \\
\left({ }^{\circ} \mathrm{C}\right)\end{array}$ & $\begin{array}{c}\text { Average Value of } \alpha_{p} \\
\left(\% /{ }^{\circ} \mathbf{C}\right)\end{array}$ \\
\hline Monocrystalline silicon & 13.50 & 47.00 & -0.48
\end{tabular}


Poly-crystalline silicon

Mono-crystalline/amorphous

Silicon hybrid

Thin film CIS

Thin film amorphous silicon
13.00

16.40

8.20

5.50
45.00

$-0.46$

By substituting efficiency at MPPT to the equation (19), the cell temperature in each time step can be calculated using new equation, as follows [35, 37]:

$$
T_{c}=\frac{T_{a}+\left(T_{c, N O C T}-T_{a, N O C T}\right)\left(\frac{G_{T}}{G_{T, N O C T}}\right)\left(1-\frac{\eta_{m p, S T C}\left(1-\alpha_{p} T_{c, S T C}\right)}{\tau \alpha}\right)}{1+\left(T_{c, N O C T}-T_{a, N O C T}\right)\left(\frac{G_{T}}{G_{T, N O C T}}\right)\left(1-\frac{\eta_{m p, S T C}}{\tau \alpha}\right)}
$$

\subsubsection{Calculates the Output Power of PV Array}

The following equation is used to compute the output power of the PV array [41-42]:

$$
P_{P V}=Y_{P V} f_{P V}\left(\frac{\bar{G}_{T}}{\bar{G}_{T, S T C}}\right)\left[1+\alpha_{p}\left(T_{c}-T_{c, S T C}\right)\right]
$$

where $Y_{P V}$ is the output power at STC, $f_{P V}$ refers to the de-rating factor of PV, GT represents the solar radiation fallen on the surface of PV array in the current time step $\left(\mathrm{kW} / \mathrm{m}^{2}\right), G T, S T C$ represents the fallen radiation at STC $\left(1 \mathrm{~kW} / \mathrm{m}^{2}\right)$.

\subsection{Configuration and Components of the Proposed System}

\subsubsection{Operating Principle}

For the proposed system configuration, the maximum power point tracking (MPPT) is used as a controller unit to maximize the produced PV output power, regardless of climatic condition variations. The solar panels work to supply the load demand. After satisfying the load demand, surplus power will be used to supply the battery storage until fully charged. When the output power from the solar panels is not enough to satisfy the load demand, the battery storage works together with the solar panels to supply the load demand until the battery storage is depleted. At night hours, the battery bank works alone to feed the load demand, since the output of PV is zero. Figure 9 shows the proposed PV/battery energy system.

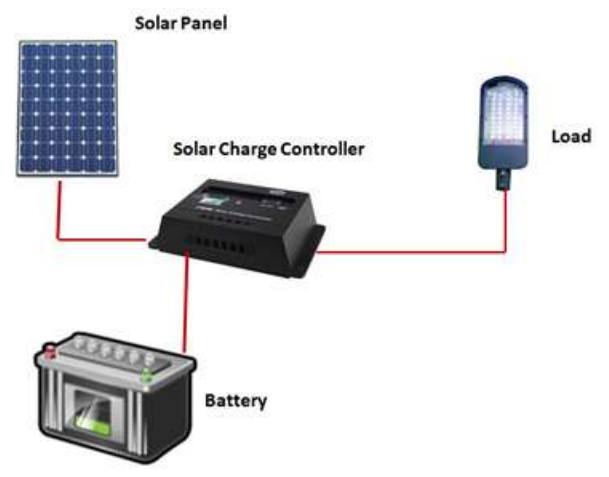

Figure 9. Typical PV/battery configuration 


\subsubsection{System Components}

\subsubsection{Photovoltaics (PV) Module}

The solar panels provide DC power directly proportional to incident solar irradiance, regardless the exposure of voltage and temperature [26, 43]. The technical and cost details of the PV module are presented in Table 4 [44-46].

Table 4. Technical and cost details of PV Module

\begin{tabular}{lc}
\hline Parameters & Value \\
\hline Tracking system & Fixed \\
Rated capacity & $1 \mathrm{~kW}$ \\
Nominal operating cell temperature & $47{ }^{\circ} \mathrm{C}$ \\
Temperature coefficient & $-0.48 \% /{ }^{\circ} \mathrm{C}$ \\
Efficiency at standard test condition & $13 \%$ \\
De-rating factor & $80 \%$ \\
Capital cost & $\$ 1500 / \mathrm{kW}$ \\
Operating and maintenance cost & $\$ 1000 / \mathrm{kW}$ \\
Cost of replacement & $\$ 5 / \mathrm{kW} / \mathrm{year}$ \\
Lifetime & 20 years \\
\hline
\end{tabular}

\subsubsection{Storage Battery}

The selected battery energy storage is Surrette 6CS25P. The batteries are arranged such that each string consists of two batteries connected in series, and strings are connected in parallel to form a battery storage bank. The technical and cost details of the battery are furnished in Table 5 [47].

Table 5. Technical and cost details of the battery

\begin{tabular}{lc}
\hline Parameter & Value \\
\hline Nominal capacity & $1156 \mathrm{Ah}(6.94 \mathrm{kWh})$ \\
Nominal voltage & $6 \mathrm{~V}$ \\
Capital cost & $\$ 1100$ \\
Replacement cost & $\$ 1000$ \\
Operating and maintenance cost & $\$ 10 /$ year \\
Minimum life & 2 years \\
Lifetime throughout & $9645 \mathrm{kWh}$ \\
\hline
\end{tabular}

\subsection{Economic Parameters}

First, the technical feasibility of various systems and whether they can meet the load demand or not is examined in HOMER. Then, the life-cycle cost of the system which is represented by the total net present cost (NPC) of the feasible systems is obtained. The following equation is used to calculate the NPC [48-50]:

$$
N P C=\frac{C_{t o t}}{C R F\left(i, T_{p}\right)}
$$


where $C_{\text {tot }}$ refers to the annual total cost (\$/year) of the system, $i$ represent the yearly real interest rate $(\%), T_{p}$ refers to the project lifetime which is 20 years in this study. The following expression is used to obtain the capital recovery factor (CRF) [48-50]:

$$
C R F(i, n)=\frac{i(1+i)^{n}}{(1+i)^{n}-1}
$$

where $n$ represents the number of years.

To calculate the NPC of the systems, the salvage costs (SC) which are the residual values of the system components by the end of the project lifetime, must be considered. It is calculated using the following expression $[48,50,51]$ :

$$
S C=C_{R C} \frac{T_{\text {rem }}}{T_{\text {com }}}
$$

where $C_{R C}$ is the cost of replacement [\$], $T_{\text {rem }}$ represents the remaining life of the component [year] and $\mathrm{T}_{\text {com }}$ refers to the component lifetime [year].

The levelized cost of energy (COE) is calculated using the following expression [49, 51, 52]:

$$
C O E=\frac{C_{t o t}}{E_{t o t}}
$$

where $E_{\text {tot }}$ refers to the total electricity consumption per year [kWh/year].

\section{Results and Discussion}

In HOMER software, a simulation is performed for all the feasible systems that feed the load demand for the proposed area under specified conditions of renewable energy sources. HOMER implements the calculations of energy balance for each system configuration based on NPC and COE in an increasing order. Then, the list of configurations are displayed and sorted by NPC [53].

\subsection{Effects of PV Tilt Angle and Orientation}

The results show that the output of PV is significantly affected by changing the slope and azimuth of the solar panels. Among various feasible systems, it is found that best tilt angles are obtained at $40^{\circ}$ and $45^{\circ}$ for azimuth of $0^{\circ}$ (facing south) which offer the lowest PV array capacity (20.6 $\mathrm{kW}$ ) with NPC of $70595 \$$ and COE of $0.54 \$ / \mathrm{kWh}$. On the other hand the result indicates that the worst case scenario is achieved when the PV is installed at slope and azimuth of $35^{\circ}$ and $180^{\circ}$ respectively, the required PV size is $84.9 \mathrm{~kW}$, which makes the system has a total NPC of 164648 \$ and COE of 1.25 which are approximately $131 \%$ more expensive than the cheapest system. Figures 10 and 11 present the impacts of PV orientation on the PV performance and its economic analysis. These results are accomplished by the fact which indicates that in the northern hemisphere, the sun is always in the south. Therefore, facing the solar panels to south will maximize the amount of sunlight reaching them. Generally, system designers install the solar panels with an azimuth angle of zero, or facing the equator since solar radiation on a south facing surface will be symmetric about solar noon [54]. If the earth's atmosphere is completely clear to solar radiation, solar array will capture more energy by facing the array due south (in the northern hemisphere) at a slope close to the value of the latitude [35]. Moreover, the current analyses of the system indicate that the azimuth angle of solar panels becomes more critical as the tilt angle of the PV array increases. The azimuth angle did not have significant effects if the tilt angles were in low values. At a $0^{\circ}$ tilt angle, the variation of azimuth angle did not show any noticeable effects on the PV size. As the tilt angles of the PV arrays increase, the orientation of the PV arrays became more influential in affecting the PV required size and the costs. However, the effect of azimuth found to be slightly less significant at $90^{\circ}$ slope than slopes between $40^{\circ}$ to $80^{\circ}$ since at $90^{\circ}$ slope, the panel sees half the sky, and for areas with low latitude, 
there will be similar in the amount of illumination in the western and southern halves of the sky. The total amount of PV production is approximately the same, although the timing is different. In general, it is clear from the results that the efficiency of the solar cell is highly affected by the variation of the slope and azimuth. It is important to mention that there is no constant relation between PV production, and optimum PV array capacity. In other words, the system with highest PV production does not necessarily result in the lowest PV size. The differences are marginal in the vicinity of the optimum point.

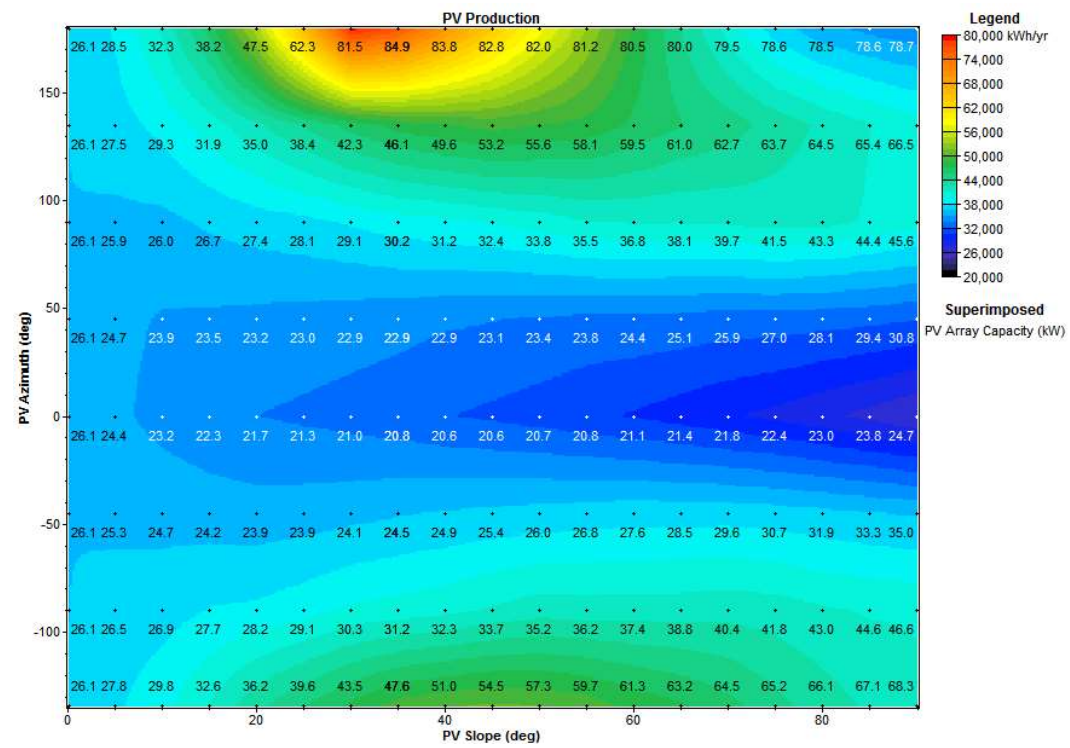

Figure 10. Impact of orientation on the PV performance

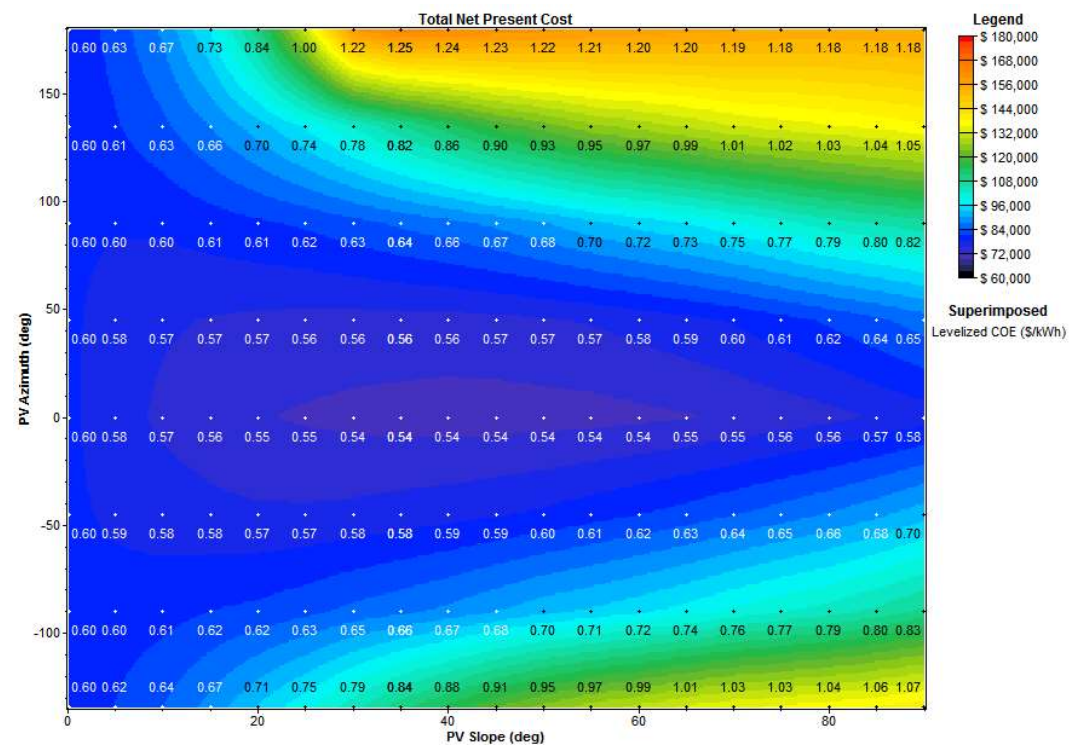

Figure 11. Impact of orientation on the NPC and COE

The recommendations for the slope angle represent an average, by considering the sun's angle throughout the year. According to the weather of Choman, it is recommended that the solar panels must be tilted at an angle on a monthly or seasonal basis in order to maximize the solar access and the output power. Figure 12 shows the average monthly incident solar with different tilt angles. It can be observed that the average monthly incident solar has a clear dependence on the tilt angle. It is found that none of the months have the same incident solar at the same tilt angles. For example, at a tilt angle of $30^{\circ}$, the average incident solar in January, June, and December are found to be 0.161107 , 
0.289838 , and $0.149135 \mathrm{~kW} / \mathrm{m}^{2}$ respectively. The optimum monthly and seasonal average tilt angles for Choman area is presented in figure 13. It is clear that the optimal tilt angle is very sensitive to the variation of the position of the sun in the various months and seasons. By varying the tilt angle from $0^{\circ}$ to $90^{\circ}$ with increment of $1^{\circ}$, the optimum PV slope angle is found to be varied between $15^{\circ}$ (June) and $60^{\circ}$ (December) throughout a year. However, adjusting the tilt angle monthly does not seem to be practical, therefore, changing the tilt angle once seasonally is a potential choice. It is found that the average optimum tilt angle for the summer months is $19^{\circ}\left(\varnothing-17^{\circ}\right)$, for the winter months $56^{\circ}\left(\varnothing+20^{\circ}\right)$, for spring months $29^{\circ}\left(\varnothing-7^{\circ}\right)$ and for the autumn months $46^{\circ}\left(\varnothing+10^{\circ}\right)$. These results are in accordance with the fact that in the Northern Hemisphere, the sun appears at its highest elevation in the sky during the summer solstice (June 21) while the noontime Sun is lowest during the winter solstice (December 21) as shown in figure 14 [55].

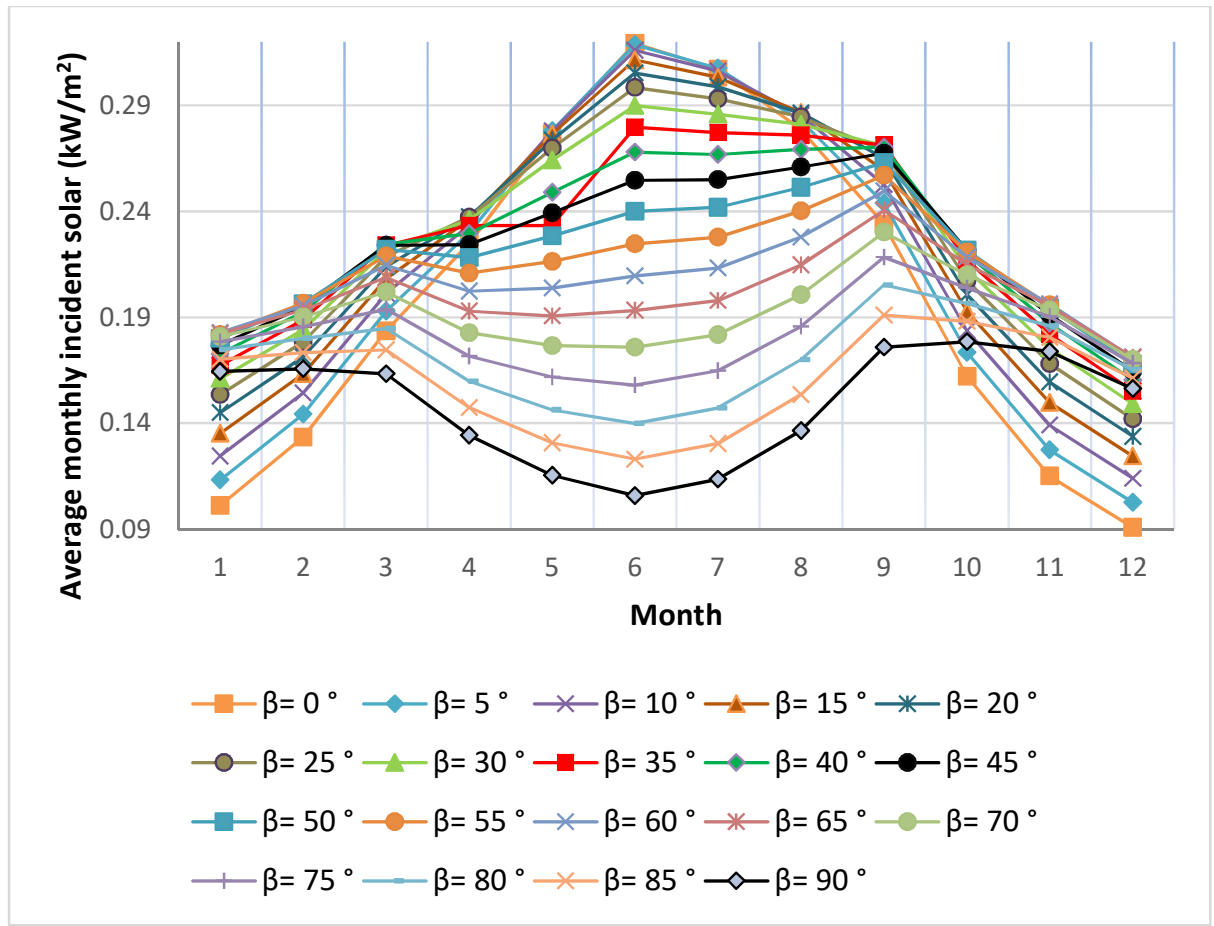

Figure 12. Average monthly incident solar with different tilt angles

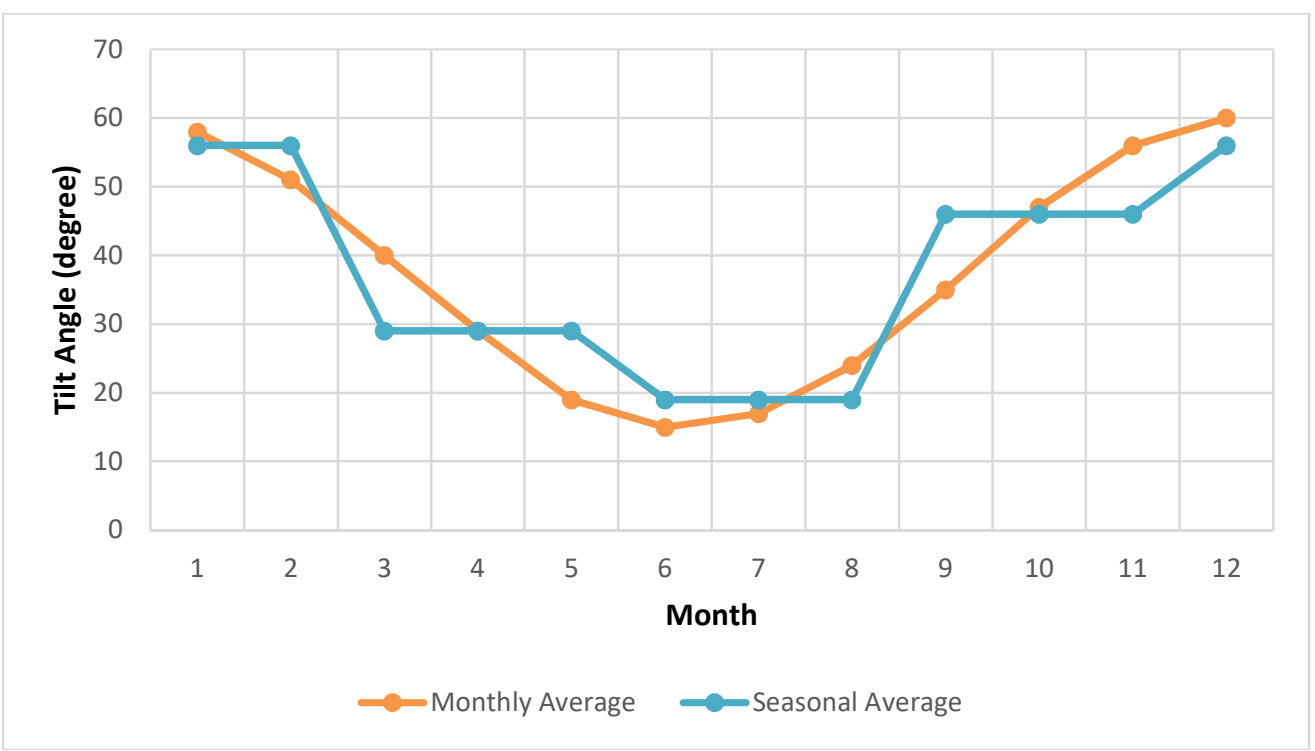

Figure 13. Monthly and seasonal optimum tilt angle for Choman 


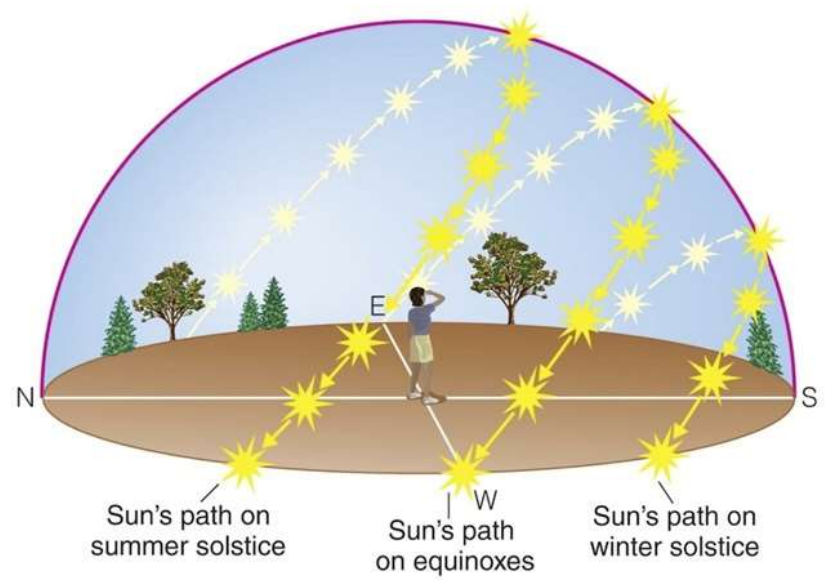

Figure 14. Sun's path during summer and winter

\subsection{Effects of the Ground Reflectance (albedo)}

As mentioned in the previous sections, the ground reflectance (also known as albedo) is a term for an object capability of reflecting the light from sources like the sun. The Albedo effect is measured on a scale from 0 to 1 , where 0 and 1 refer to the dark and light respectively. In this part of the simulation, a sensitivity analysis has been done to investigate the impact of ground reflectance on the performance of PV and its total cost. From figures 15, 16, it is clear that for higher the albedo values, the reflected irradiance on the PV module is higher and hence the output power generated is higher which leads to reduce both the required PV size and the net present cost of the system. It can be seen that the variation in the ground reflectance $10 \%$ to $90 \%$ increase the average annual incident solar radiation on PV array from 0.223579 to $0.242538 \mathrm{~kW} / \mathrm{m}^{2}$ while reduces the PV array capacity from 20.8 to $19.4 \mathrm{~kW}$, net present cost from 70888 to 68840 \$, and cost of energy from 0.53959 to 0.52398 $\$ / \mathrm{kWh}$. These results indicate that snow cover surface which has ground reflectance of about $90 \%$ achieves the best result as compared to all other ground cover types, especially the dark colored surfaces. This can be explained by the fact that lighter ground means more reflectance of solar radiation on the solar panels. Ground with snow covers is usually even brighter than the sky. Whilst, darker surface absorbs most of the light, meaning less is reflected [56]. However, although the albedo of the surfaces is recommended to be higher, other issues such as damages by strong winds and snow must be taken into account when obtaining the optimum size of solar panels. Moreover, increasing the ground reflectance is found to increase the cell temperature as shown in figure 17.

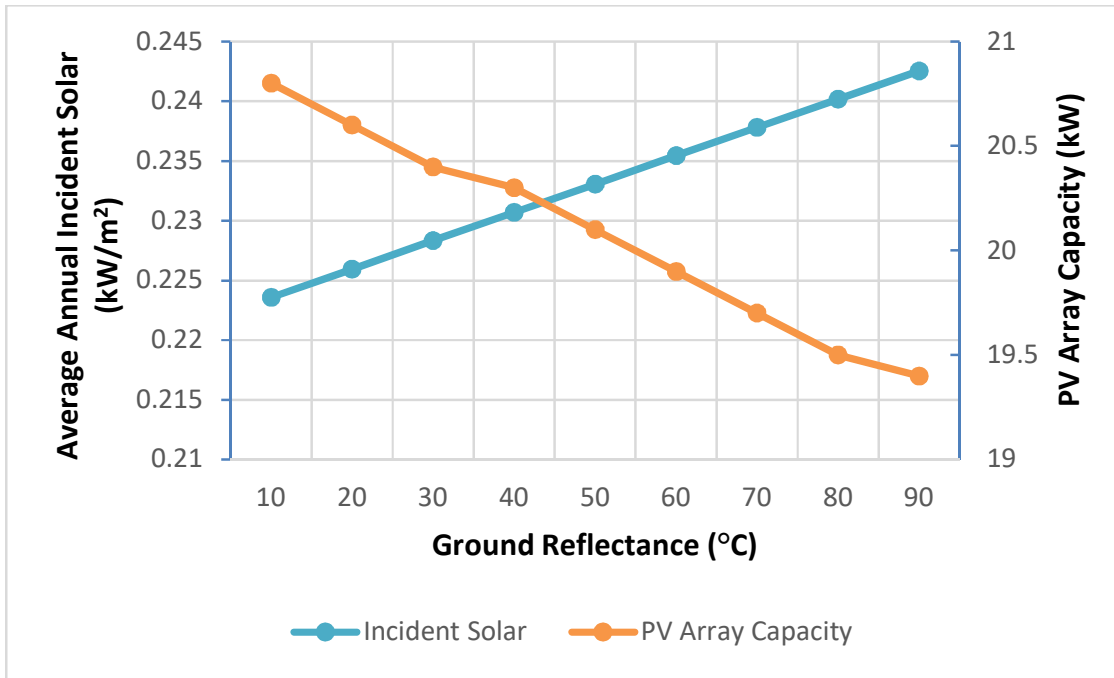

Figure 15. Impact of the ground reflectance on PV required capacity and incident solar radiation 


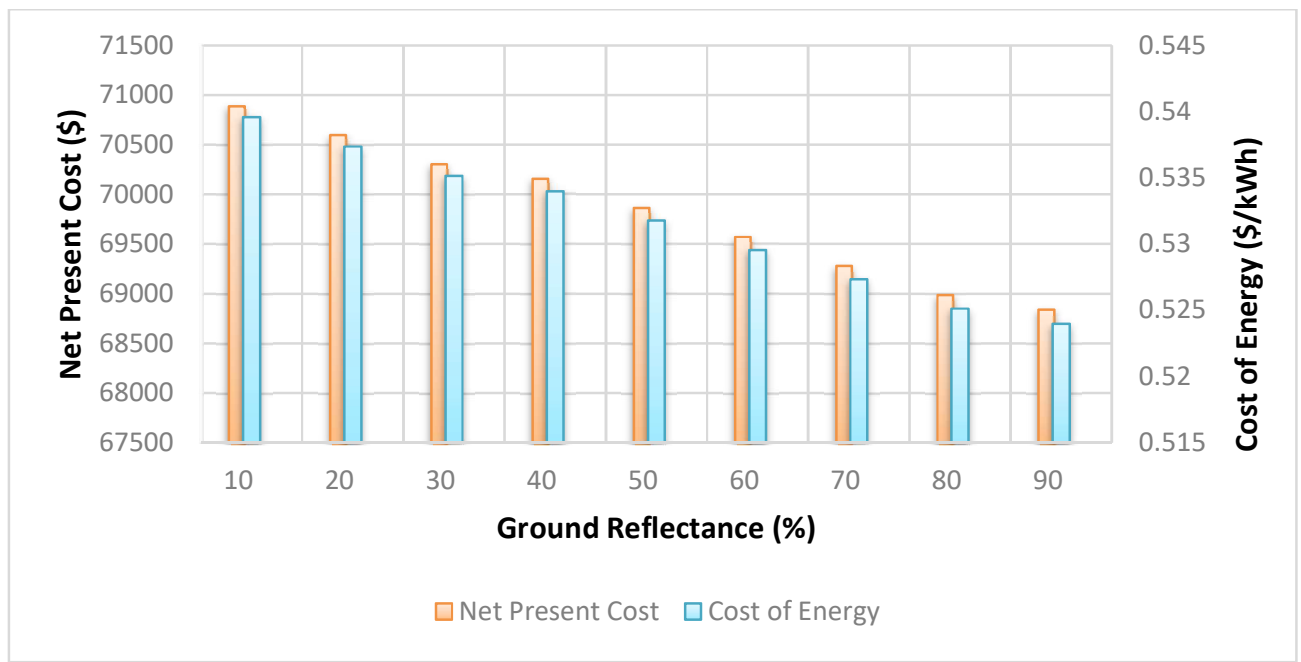

Figure 16. Impact of the ground reflectance on NPC and COE

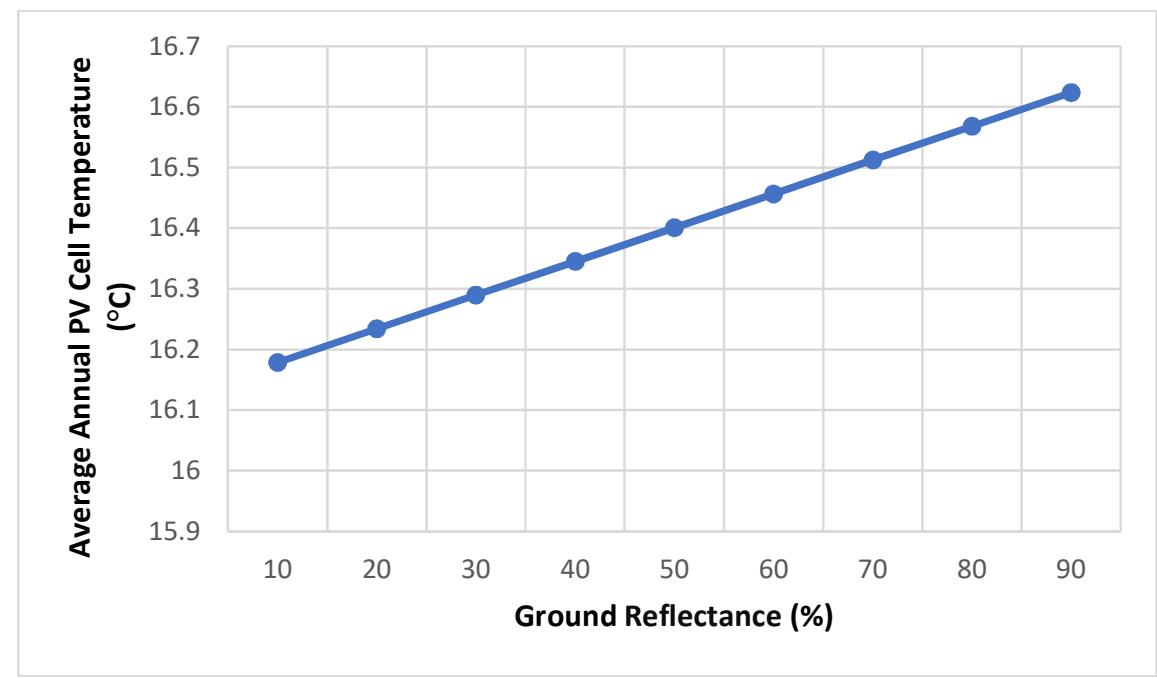

Figure 17. Impact of the ground reflectance on PV cell temperature

\subsection{Effects of the Ambient Temperature and Temperature Coefficient of Power}

For most of the commonly used solar panels, a ratio of the sun's energy converted into electric power is usually ranges between $13 \%$ to $20 \%$, the remainder is converted into thermal energy that heats the cells. Moreover, further heating occurs due the solar panel's actions and the radiation of energy at the infrared wavelength of the solar spectrum [57]. This heat result in an increase in the overall PV cell temperature. Temperature affects the flow of the electric current in the electrical circuits since it changes the traveling speed of the electrons because of the increase in resistance of the circuit as a result of the temperature increasing [58]. The impact of cell temperature on the performance of PV and its cost is analyzed in this part. The relation between cell temperature and ambient temperature is shown in figure 18. It is clear from the results that the cell temperature can exceed the ambient temperature with $25^{\circ} \mathrm{C}$ or up. Increasing the ambient temperature from $-3.3{ }^{\circ} \mathrm{C}$ in January to $23.8^{\circ} \mathrm{C}$ in July causes the cell temperature to be increased from 25.8 to $50.2^{\circ} \mathrm{C}$. The high cell temperature leads to reduction in PV output power and hence reduction in system efficiency as shown in figure 19. It is obvious that the PV output power decreases from 20.6 to $15.4 \mathrm{~kW}$ when the $\mathrm{PV}$ cell temperature increases from 25.8 to $50.2^{\circ} \mathrm{C}$ (January to July). The impact of variation of the average ambient temperature on the PV array capacity, net present cost, and cost of energy are presented in figures 20 and 21. The results show an increasing in PV array capacity from 19.8 to 23.1 $\mathrm{kW}$, NPC from 69425 to $75129 \$$, and COE from 0.52840 to $0.57186 \$ / \mathrm{kWh}$ when the average ambient 
temperature increases from 0 to $40{ }^{\circ} \mathrm{C}$. Currently, there is interest to increase the efficiency of PV by reducing the cell temperature using different cooling methods [59-63].

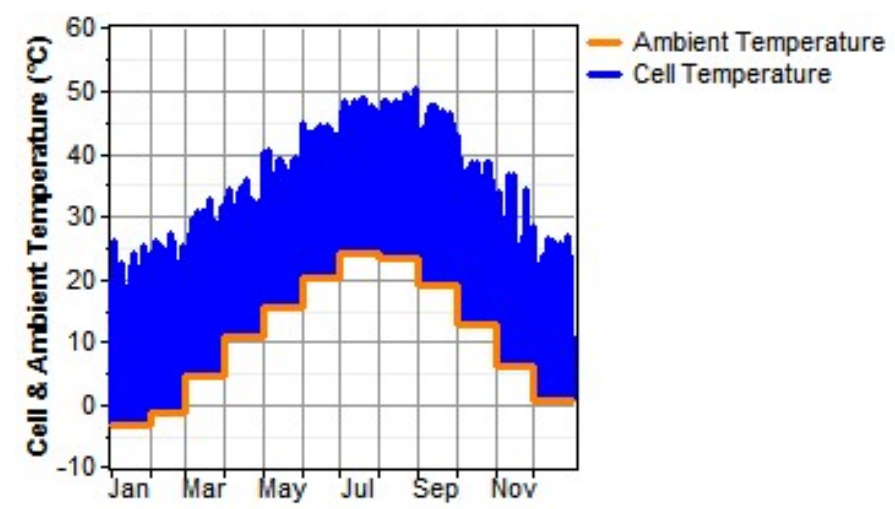

Figure 18. Relation between ambient and PV cell temperature

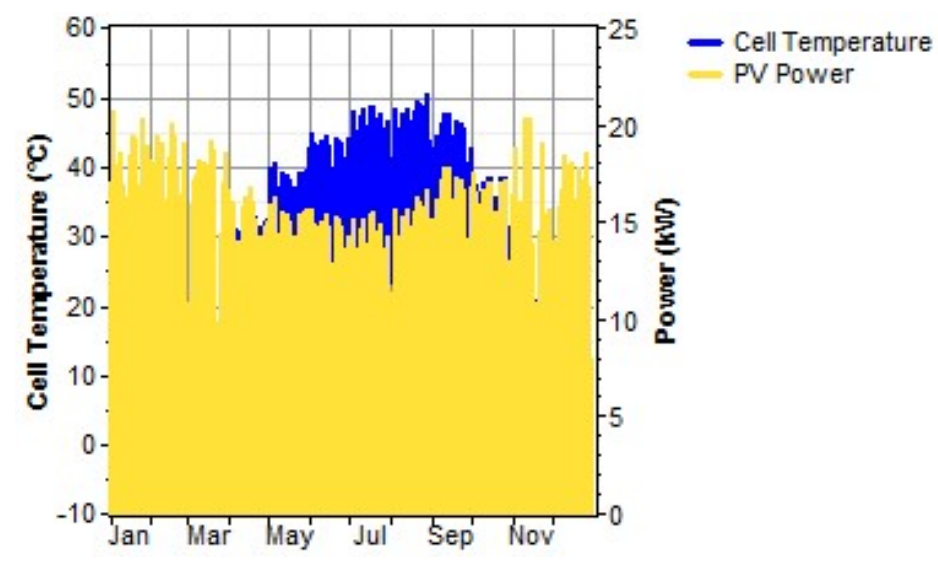

Figure 19. The effect of PV cell temperature on the output power

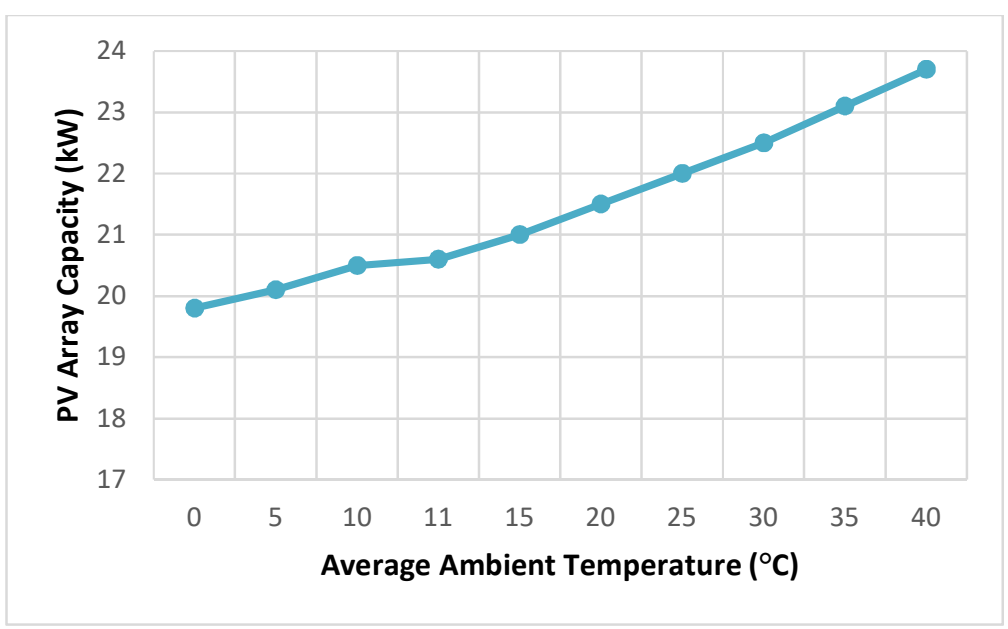

Figure 20. The effect of ambient temperature on PV array size

Products' susceptibility to temperature is usually rated by manufacturers in the term of the temperature coefficient, which is usually given in a percent per degree Celsius [64, 65]. Table 6 presents the temperature coefficient of power for some common PV modules [66]. Solar panels are tested at a temperature of $25^{\circ} \mathrm{C}$. With a temperature coefficient of power of $-0.35 \% /{ }^{\circ} \mathrm{C}$, there will be losses of $0.35 \%$ in $\mathrm{PV}$ output power for every $1^{\circ} \mathrm{C}$ increase. On the other hand, when temperatures are lower than $25^{\circ} \mathrm{C}$, the temperature coefficient will actually be positive, and the output power of 


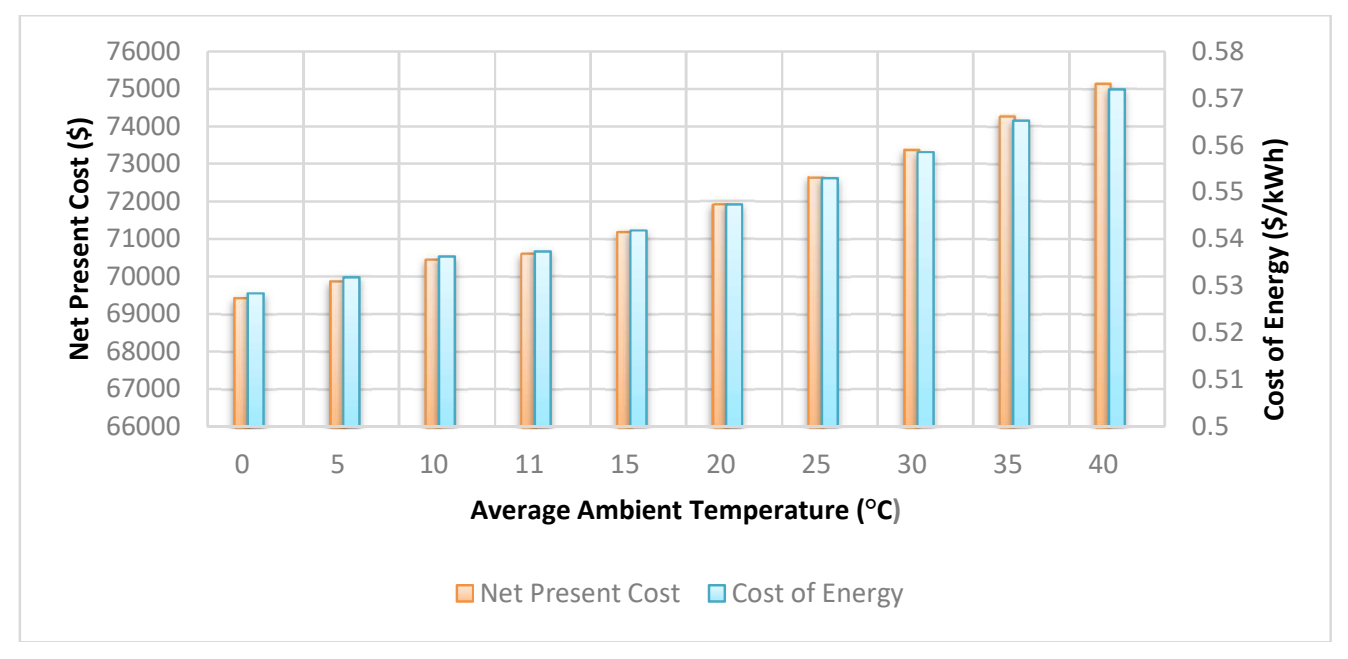

Figure 21. The effect of ambient temperature on NPC and COE

Table 6. The temperature coefficient of power for some common PV modules

\begin{tabular}{ccc}
\hline PV module type & Manufacturer & $\begin{array}{c}\text { Temperature coefficient of power } \\
\mathbf{( \% /} /{ }^{\mathbf{C}} \mathbf{)}\end{array}$ \\
\hline CAT 115 & Caterpillar Inc. & -0.28 \\
Canadian Solar All-Black CS6K-290 MS & Canadian Solar & -0.39 \\
Enphase IQ6plus with Generic PV & Enphase & -0.41 \\
First Solar Series 4-107 & First Solar & -0.34 \\
Fronius Galvo 3.1-1 with Generic PV & Fronius & -0.41 \\
Hanwha Q.plus BFR- G4.1 & Hanwha Q Cells & -0.4 \\
Huawei SUN 2000 25 KW with Generic PV & Huawei & -0.41 \\
JA Jam6 60-270 & JA Solar & -0.41 \\
Jinko Eagle PERC 60 300W & Jinko Solar & -0.39 \\
Kyocera KD 145 SX-UFU & Kyocera & -0.46 \\
LONGi LR6-72HV-350M & LONGi Solar & -0.41 \\
Sharp ND-250QCS & SMA & -0.41 \\
SMA Sunny Tripower 60-US with Generic PV & Sharp & -0.485 \\
SolarMax 500RX A with Generic PV & SolarMax & -0.41 \\
SunPower X21-335-BLK & SunPower & -0.3 \\
Trina Allmax M plus & Trina Solar & -0.39 \\
Ingeteam (1164 KV) with Generic PV & Ingeteam & -0.41 \\
\hline
\end{tabular}

PV arrays will increase $[67,68]$. Therefore, cold and sunny days achieve the maximum power of the panels. In this section a simulation has been done in order to investigate the impact of cell temperature coefficient variation on the required PV size. From figure 22, it is obvious that variation of temperature coefficient from -0.6 to $-0.1 \% /{ }^{\circ} \mathrm{C}$ causes the required $\mathrm{PV}$ array capacity to be increased for an average ambient temperature between $0{ }^{\circ} \mathrm{C}$ and $25{ }^{\circ} \mathrm{C}$. While, for an average ambient temperature of $30^{\circ} \mathrm{C}$ to $40^{\circ} \mathrm{C}$, these variations result in a decrease of the needed PV size. For Choman area which has an average annual ambient of $11^{\circ} \mathrm{C}$, the utilization of solar panels that have high sensitivity to temperature, such as poly-crystalline silicon and thin film CIS are found to be preferable 
since the PV works for a long time with a cell temperature below $25{ }^{\circ} \mathrm{C}$. Therefore, the gain of efficiency during cold months helps to compensate losses that occur during the hot weather months.

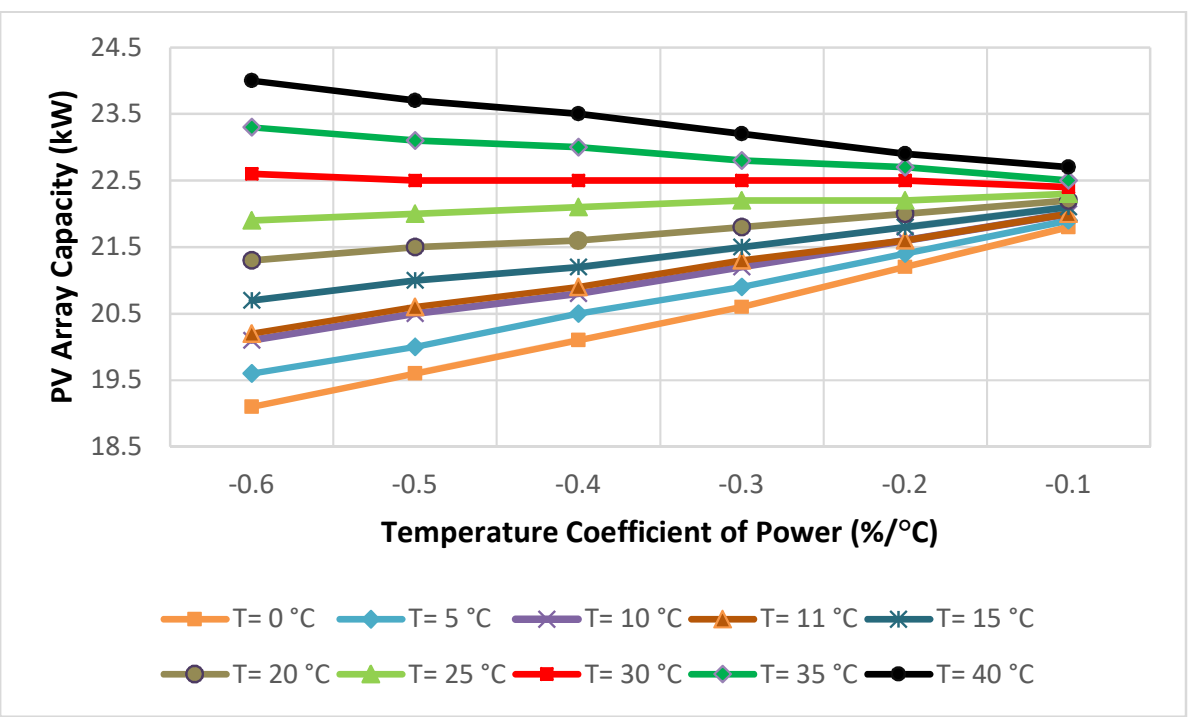

Figure 22. The effect of temperature coefficient of power on PV array capacity

\section{Conclusion}

PV cell temperature and the solar radiation incident on the surface of the panels are highly affected by the ambient temperature, slope and azimuth angles, and ground reflectance. Therefore, the variation of these parameters must be strongly considered in the optimization of the performance of the solar system. The present work deals with not only the technical performance of the solar system, but also with its economic analysis in terms of net present cost (NPC) and cost of energy (COE). According to the simulation results of HOMER, it has been demonstrated that varying the tilt angle of PV on a seasonal basis with an azimuth of $0^{\circ}$ (facing south) can highly maximize the solar panel efficiency. Furthermore, it is found that the ground reflectance (albedo) variation has considerable effects on the output power of the system. A fresh snow cover surface which has the highest albedo compares to other covers, achieves the best results. Moreover, according to the climate condition of Choman, the ambient temperature is observed to be another important factor which highly influences the technical analysis of the system. However, selecting of PV modules with high sensitivity to temperature is found to be a preferable option. Consequently, the economic feasibility of the system is highly influenced by the variations of all these factors. The best tilt angles are obtained at $40^{\circ}$ and $45^{\circ}$ for an azimuth of $0^{\circ}$ in which the system has NPC of $70595 \$$ and COE of $0.54 \$ / \mathrm{kWh}$, which are $131 \%$ cheaper than the worst case( tilt angle and azimuth of $35^{\circ}$ and $180^{\circ}$ respectively). Nevertheless, there is about 3\% decrease in the NPC and COE for ground reflectance varied from 10 to $90 \%$. On the other hand, increasing the ambient temperature from 0 to $40{ }^{\circ} \mathrm{C}$ causes a $19.7 \%$ increase in the PV array capacity and an 8.2\% increase in the NPC and COE. As a conclusion, the present work could produce a realistic estimation regarding the implementation of solar energy systems and served as a basis for the standardization entities, component manufacturers, energy prosumers and policy makers in Iraq.

Author Contributions: The authors participated evenly in framing the research survey and execute the task with writing this manuscript in current full research article format.

Conflicts of Interest: The authors declare no conflict of interest.

\section{References}


1. Isa, N.M.; Das, H.S.; Tan, C.W.; Yatim, A.H.M.; Lau, K.Y. A techno-economic assessment of a combined heat and power photovoltaic/fuel cell/battery energy system in Malaysia hospital. Energy 2016, 112, 75-90. DOI: https://doi.org/10.1016/j.energy.2016.06.056

2. Khan, M.A.; Zeb , K.; Sathishkumar, P.; Himanshu; Rao, S.S.; Gopi, C.V.V.M.; Kim, H. A novel off-grid optimal hybrid energy system for rural electrification of Tanzania using a closed loop cooled solar system. energies, 2018, 11, 1-22. DOI: 10.3390/en11040905

3. Das, H.S.; Tan, C.W.; Yatim, A.H.M.; Lau, K.Y. Feasibility analysis of hybrid photovoltaic/battery/fuel cell energy system for an indigenous residence in East Malaysia. Renew. Sustain. Energy Rev. 2017, 76, 1332-1347. DOI: 10.1016/j.rser.2017.01.174

4. Abdilahi, A.M.; Yatim, A.H. M.; Mustafa, M.W.; Khalaf, O.T.; Shumran, A.F.; Nor, F. M. Feasibility study of renewable energy-based microgrid system in Somaliland' s urban centers. Renew. Sustain. Energy Rev. 2014, 40, 1048-1059. DOI: https://doi.org/10.1016/j.rser.2014.07.150

5. Díaz, P.; Adler, C.; Patt, A. Do stakeholders' perspectives on renewable energy infrastructure pose a risk to energy policy implementation? A case of a hydropower plant in Switzerland. Energy Policy 2017, 108, 21-28. DOI: https://doi.org/10.1016/j.enpol.2017.05.033

6. Nag, A.K.; Sarkar, S. Modeling of hybrid energy system for futuristic energy demand of an Indian rural area and their optimal and sensitivity analysis. Renew. Energy 2018, 477-488. DOI: 10.1016/j.renene.2017.11.047

7. Sieminski, A. International energy outlook. Energy. 2014. Available online: http://energypolicy.columbia.edu/sites/default/files/Columbia_Sieminski\%20IEO\%202014_for \%20web.pdf (accessed on 20/03/ 2018).

8. Brennan, M.P.; Abramase, A.L.; Andrews, R.W.; Pearce, J.M. Effects of spectral albedo on solar photovoltaic devices. Sol. Energy Mater. Sol. Cells 2014, 124, 111-116. DOI: https://doi.org/10.1016/j.solmat.2014.01.046

9. Pradhan, A.; Panda, B. Experimental analysis of factors affecting the power output of the PV module. Int. J. Electr. Comput. Eng. 2017, 7, 3190-3197. DOI: 10.11591/ijece.v7i6.pp3190-3197

10. Janssen, R.A.J.; Nelson, J. Factors limiting device efficiency in organic photovoltaics. Adv. Mater. 2013, 25, 1847-1858. DOI: https://doi.org/10.1002/adma.201202873

11. Elminir, H.K.; Benda, V.; Tousek, J. Effects of solar irradiation conditions and other factors on the outdoor performance of photovoltaic modules. J. Electr. Eng. 2001, 52, 125-133.

12. Ike, C.U. The effect of temperature on the performance of a photovoltaic solar system in eastern Nigeria. Int. J. Eng. Sci. 2013, 3, 10-14.

13. Khalis, M.; Masrour, R.; Khrypunov; G.; Kirichenko, M.; Kudiy, D.; Zazoui, M. Effects of temperature and concentration mono and polycrystalline silicon solar cells: extraction parameters. J. Phys. Conf. Ser. 2016, 758, 1-10. DOI: 10.1088/1742-6596/758/1/012001

14. Nacer, T.; Hamidat, A., Nadjemi; O., Bey, M. Feasibility study of grid connected photovoltaic system in family farms for electricity generation in rural areas. Renew. Energy 2016, 96, 305-18. DOI: https://doi.org/10.1016/j.renene.2016.04.093

15. Lee, J.F.; Rahim, N.A.; Al-Turki, Y.A. Performance of dual-axis solar tracker versus static solar system by segmented clearness index in Malaysia. Int. J. Photoenergy 2013, 2013, 1-13. DOI: http://dx.doi.org/10.1155/2013/820714

16. Goto, D.; Takemura, T.; Nakajima, T.; Badarinath, K.V.S. Global aerosol model-derived black carbon concentration and single scattering albedo over Indian region and its comparison with ground observations. Atmos. Environ. 2011, 45, 3277-3285. DOI: https://doi.org/10.1016/j.atmosenv.2011.03.037

17. Alton, P.A. Simple retrieval of ground albedo and vegetation absorptance from MODIS satellite data for parameterisation of global land-surface models. Agric. For. Meteorol. 2009, 149, 1769-75. DOI: https://doi.org/10.1016/j.agrformet.2009.04.012

18. He, T.; Liang, S.; Wang, D.; Wu, H.; Yu, Y.; Wang, J. Estimation of surface albedo and directional reflectance from Moderate Resolution Imaging Spectroradiometer (MODIS) observations. Remote Sens. Environ. 2012, 119, 286-300. DOI: https://doi.org/10.1016/j.rse.2012.01.004 
19. Guechi, A.; Chegaar, M. The Effect of ground albedo on the performance GaInP and (a-Si: $\mathrm{H})$ of Solar Cells. J. New. Technol. Mater. 2014, 4, 31-4. DOI: 10.12816/0010294

20. Kotak, Y.; Gul, M.S. Muneer T, Ivanova SM. Impact of ground albedo on the performance of PV systems and its economic analysis. 7th International Conference on Solar Radiation and Daylight, Celje, Slovenia, 21-22 May 2015, p. 1-4.

21. Soulayman, S.; Sabbagh, W. Optimum tilt angle at tropical region. Int. J. Renew. Energy Dev. 2015, 4, 48. DOI: 10.14710/ijred.4.1.48-54

22. Belay, Y.; Amente, G.; Goro, G. Estimation of solar panel orientation with different tilt angles at Haramaya. PhD Thesis, Haramaya University, 2014.

23. Sultan, F.; Ali, F.A.; Razaq, T.K.A. Tilt angle optimization of solar collectors for maximum radiation in three Iraqi cities. Int. J. Eng. Ind. 2012, 3, 99-107. DOI: 10.4156/IJEI.vol3.issue4.11

24. Benghanem, M. Optimization of tilt angle for solar panel: Case study for Madinah, Saudi Arabia. Appl. Energy 2011, 88, 1427-1433. DOI: https://doi.org/10.1016/j.apenergy.2010.10.001

25. Mansouri, E.; Pirsalami, M.; Nasiri, N.; Farrizi, M.; Hashemizadeh, M.; Alihosseini, H. Optimum tilt angle for fixed-array solar panels at a constant latitude of 29 to receive the maximum sunlight. Bull. Env. Pharmacol. Life Sci. 2016, [Spl Issue 1], 26:30. DOI: http://doids.org/doilink/05.2016-13212626/

26. Li, C.; Ge, X.; Zheng, Y.; Xu, C.; Ren, Y.; Song, C.; et al. Techno-economic feasibility study of autonomous hybrid wind/PV/battery power system for a household in Urumqi, China. Energy 2013, 55, 263-272. DOI: https://doi.org/10.1016/j.energy.2013.03.084

27. Waqar, A.; Tanveer, M.S.; Ahmad, J.; Aamir, M.; Yaqoob, M.; Anwar, F. Multi-objective analysis of a CHP plant integrated microgrid in Pakistan. Energies, 2017, 10, 1-22. DOI: 10.3390/en10101625

28. Haratian, M.; Tabibi, P.; Sadeghi, M.; Vaseghi, B.; Poustdouz, A.A. Renewable energy solution for stand-alone power generation: A case study of KhshU site-Iran. Renew. Energy 2018, 125, 926-935. DOI: 10.1016/j.renene.2018.02.078

29. Sakran Mountain (E14). 2010. Availale online: www.natureiraq.org/uploads/9/2/7/0/9270858/sakran_mt-e14.pdf [accessed 15/4/2018].

30. Aziz, A.S.; Khudhier, S.A. Optimal planning and design of an environmentally friendly hybrid energy system for rural electrification in Iraq. Am. J. Appl. Sci. 2017, 14, 157-65. DOI: 10.3844/ajassp.2017.157.165

31. Weather statistics for Choman (Iraq). Available online: https://www.yr.no/sted/Irak/Arbil/Choman/ [accessed 15/4/2018].

32. Mouli, G.R.C.; Bauer, P.; Zeman, M. System design for a solar powered electric vehicle charging station for workplaces. Appl. Energy 2016, 168, 434-43. DOI: https://doi.org/10.1016/j.apenergy.2016.01.110

33. Ramli, M.A.M.; Hiendro, A.; Al-Turki, Y.A. Techno-economic energy analysis of wind/solar hybrid system: Case study for western coastal area of Saudi Arabia. Renew. Energy 2016, 91, 374-85. DOI: https://doi.org/10.1016/j.renene.2016.01.071

34. Bhakta, S.; Mukherjee, V. Techno-economic viability analysis of fixed-tilt and two axis tracking stand-alone photovoltaic power system for Indian bio-climatic classification zones. J. Renew. Sustain. Energy 2017, 9, 1-45. DOI: https://doi.org/10.1063/1.4976119

35. Lau, K.Y.; Tan, C.W.; Yatim, A.H.M. Effects of ambient temperatures, tilt angles, and orientations on hybrid photovoltaic/diesel systems under equatorial climates. Renew. Sustain. Energy Rev. 2017, 81, 2625-2636. DOI: https://doi.org/10.1016/j.rser.2017.06.068

36. Chandrakar, A.; Tiwari, Y. Optimization of solar power by varying tilt angle/slope. Int. J. Emerg. Technol. Adv. Eng. 2013, 3, 145-150.

37. Tesfaye, B. Improved Sustainable Power Supply for Dagahabur and Kebridahar Town of Somalia Region in Ethiopia. Master Thesis, Reykjavik University, Reykjavík, Iceland, 2011.

38. Ahrens, C.D.; Jackson, P. L.; Jackson, C.E.O. Meteorology today: an introduction to weather, climate, and the environment. 9th Edition. Cengage Learning; 2012. ISBN: 0176500391, 9780176500399 
39. Baneshi, M.; Hadianfard, F. Techno-economic feasibility of hybrid diesel/PV/wind/battery electricity generation systems for non-residential large electricity consumers under southern Iran climate conditions. Energy Convers. Manag. 2016, 127, 233-44. DOI: https://doi.org/10.1016/j.enconman.2016.09.008

40. Karki, I.B. Effect of temperature on the IV characteristics of a polycrystalline solar cell. J. Nepal. Phys. Soc. 2016, 3, 35-40. DOI: http://dx.doi.org/10.3126/jnphyssoc.v3i1.14440

41. Sinha, S.; Chandel, S.S. Prospects of solar photovoltaic-micro-wind based hybrid power systems in western Himalayan state of Himachal Pradesh in India. Energy Convers. Manag. 2015, 105, 1340-1351. DOI: https://doi.org/10.1016/j.enconman.2015.08.078

42. Olatomiwa, L. Optimal configuration assessments of hybrid renewable power supply for rural healthcare facilities. Energy Reports. 2016, 2, 141-146. DOI: https://doi.org/10.1016/j.egyr.2016.06.001

43. Isa, N.M.; Tan, C.W.; Yatim A.H.M. A techno-economic assessment of grid connected photovoltaic system for hospital building in Malaysia. IOP Conference Series: Materials Science and Engineering, 2017, 217, 1-12. DOI: 10.1088/1757-899X/217/1/012016

44. Al Garni, H.; Awasthi, A. Techno-economic feasibility analysis of a solar pv grid-connected system with different tracking using HOMER software. 2017 IEEE International Conference on Smart Energy Grid Engineering, Oshawa, ON, Canada, 2017, 217-222.

45. Özkök, A.; Güler, Ö. Economic analysis of domestic electricity production by roof-top photovoltaic systems in two Provinces of Turkey. Engineering and Industry Series Volume Deregulated Electricity Market Issues in South Eastern Europe. 2015, 160-165.

46. Lao, C.; Chungpaibulpatana, S. Techno-economic analysis of hybrid system for rural electrification in Cambodia. Energy Procedia. 2017, 138, 524-529. DOI:

https://doi.org/10.1016/j.egypro.2017.10.239

47. Fazelpour, F.; Soltani, N.; Rosen, M.A. Economic analysis of standalone hybrid energy systems for application in Tehran, Iran. Int. J. Hydrogen Energy 2016, 41, 7732-7743. DOI: https://doi.org/10.1016/j.ijhydene.2016.01.113

48. Alsharif, M.H.; Kim, J. Hybrid off-grid SPV/WTG power system for remote cellular base stations towards green and sustainable cellular networks in South Korea. 2017, 10, 1-23. DOI: 10.3390/en10010009

49. Singh, A.; Baredar, P.; Gupta, B. Techno-economic feasibility analysis of hydrogen fuel cell and solar photovoltaic hybrid renewable energy system for academic research building. Energy Convers. Manag. 2017, 145, 398-414. DOI: https://doi.org/10.1016/j.enconman.2017.05.014

50. Oviroh, P. O.; Jen, T. C. The energy cost analysis of hybrid systems and diesel generators in powering selected base transceiver station locations in Nigeria. Energies 2018, 11, 1-20. DOI: 10.3390/en11030687

51. Mamaghani, A.H.; Escandon, S.A.A.; Najafi, B.; Shirazi, A.; Rinaldi, F. Techno-economic feasibility of photovoltaic, wind, diesel and hybrid electrification systems for off-grid rural electrification in Colombia. Renew. Energy 2016, 97, 293-305. DOI: https://doi.org/10.1016/j.renene.2016.05.086

52. Alam, M.; Bhattacharyya, S. Decentralized renewable hybrid mini-grids for sustainable electrification of the off-grid coastal areas of Bangladesh. Energies, 2016, 9, 1-16. DOI: 10.3390/en9040268

53. Nandi, S.K.; Ghosh, H.R. Prospect of wind-PV-battery hybrid power system as an alternative to grid extension in Bangladesh. Energy 2010, 35, 3040-3047. DOI: https://doi.org/10.1016/j.energy.2010.03.044

54. Gualla, F. Sun position and PV panels: a model to determine the best orientation. Master Thesis, Lund University, Lund, Sweden, 2015.

55. Koupelis, T. In quest of the universe. Jones \& Bartlett Publishers, 2012, ISBN: 1449647944, 9781449647940

56. Li, H.; Harvey, J.T.; Holland, T.J.; Kayhanian, M. The use of reflective and permeable pavements as a potential practice for heat island mitigation and stormwater management. Environ. Res. Lett. 2013, 8, 15023. DOI: http://dx.doi.org/10.1088/1748-9326/8/1/015023 
57. Armstrong, S.; Hurley, W.G. A thermal model for photovoltaic panels under varying atmospheric conditions. Appl. Therm. Eng. 2010, 30, 1488-1495. DOI: https://doi.org/10.1016/j.applthermaleng.2010.03.012

58. Chander, S.; Purohit, A.; Sharma, A.; Nehra, S.P.; Dhaka, M.S. Impact of temperature on performance of series and parallel connected mono-crystalline silicon solar cells. Energy Reports 2015, 1, 175-80. DOI: https://doi.org/10.1016/j.egyr.2015.09.001

59. Popovici, C.G.; Hudişteanu, S.V.; Mateescu, T.D.; Cherecheş, N-C. Efficiency improvement of photovoltaic panels by using air cooled heat sinks. Energy Procedia 2016, 85, 425-32. DOI: https://doi.org/10.1016/j.egypro.2015.12.223

60. Hachicha, A.A.; Ghenai, C.; Hamid, A.K. Enhancing the performance of a photovoltaic module using different cooling methods. Int. J. Energy Power Eng. 2015, 9, 1106-1109.

61. Sargunanathan, S.; Elango, A.; Mohideen, S.T. Performance enhancement of solar photovoltaic cells using effective cooling methods: A review. Renew. Sustain. Energy. Rev. 2016, 64, 382-93. DOI: https://doi.org/10.1016/j.rser.2016.06.024

62. Nižetić, S.; Papadopoulos, A.M.; Giama, E. Comprehensive analysis and general economicenvironmental evaluation of cooling techniques for photovoltaic panels, Part I: Passive cooling techniques. Energy Convers. Manag. 2017, 149, 334-354. DOI: https://doi.org/10.1016/j.enconman.2017.07.022

63. Alami, A.H. Effects of evaporative cooling on efficiency of photovoltaic modules. Energy Convers. Manag. 2014, 77, 668-679. DOI: https://doi.org/10.1016/j.enconman.2013.10.019

64. Fesharaki, V.J.; Dehghani, M.; Fesharaki, J.J.; Tavasoli, H. The effect of temperature on photovoltaic cell efficiency. Proceedings of the 1st International Conference on Emerging Trends in Energy Conservation. Tehran, Iran, 2011, p. 20-1.

65. Trentadue, G.; Pavanello, D.; Salis, E. Field M, Müllejans H. Determination of internal series resistance of PV devices: repeatability and uncertainty. Meas. Sci. Technol. 2016, 27, 1-9. DOI: 10.1088/0957-0233/27/5/055005

66. Go Solar California. 2018. Availale online: http://www.gosolarcalifornia.ca.gov/equipment/pv_modules.php [accessed 15/2/2018].

67. Zheng, B. Prince PE. Purchasing efficiency measurement of selected chinese PV panels using data envelopment analysis (DEA). Undergrad. Rev. 2015, 11, 148-155.

68. Buday, M. Measuring irradiance, temperature, and angle incidence effects on photovoltaic modules in Auburn Hills, Michigan. Master Thesis, University of Michigan, Michigan, US, 2011. 